Check for updates

Cite this: RSC Adv., 2017, 7, 22388

Received 8th February 2017

Accepted 2nd April 2017

DOI: 10.1039/c6ra28851k

rsc.li/rsc-advances

\section{Synthesis and evaluation of novel F-18-labeled pyrimidine derivatives: potential FAK inhibitors and PET imaging agents for cancer detection $\dagger$}

\begin{abstract}
Dawei Wang, (D) Yu Fang, Hang Wang, Xingyu Xu, Jianping Liu and Huabei Zhang*
Based on computer-assisted drug design, a series of novel pyrimidine derivatives was successfully synthesized and characterized by ${ }^{1} \mathrm{H} N M R,{ }^{13} \mathrm{C} H N M R$, and MS spectra. All the new compounds were evaluated for their activity against focal adhesion kinase and showed low $\mathrm{IC}_{50}$ values in comparison with control drugs. In particular, for compound $8 \mathrm{i}$, its $I_{50}$ value was $0.060 \mu \mathrm{M}$, suggesting its advantage as a focal adhesion kinase inhibitor. To evaluate the potentiality of these compounds as PET imaging agents in cancer detection, compounds $8 \mathrm{a}, 8 \mathrm{c}, 8 \mathrm{~h}$, and $8 \mathrm{i}$ were successively labeled with ${ }^{18} \mathrm{~F}$. The four ${ }^{18} \mathrm{~F}-$ labeled pyrimidine derivatives showed appropriate $\log P$ values and high stability in physiological saline and mouse plasma. Noticeably, compound $\left[{ }^{18} \mathrm{~F}\right]-8 \mathrm{a}$ with a 4 -methoxyl group at the benzene ring exhibited good in vivo biodistribution data in mice bearing the S180 tumor, which promoted a further microPET imaging study of compound $\left[{ }^{18} \mathrm{~F}\right]-8 \mathrm{a}$. The microPET image of $\left[{ }^{18} \mathrm{~F}-8 \mathrm{a}\right]$ administered into the S180 tumor-bearing mice acquired at 60 min post-injection illustrated that the uptake in S180 tumor was obvious. These results suggested that compound $\left[{ }^{18} \mathrm{~F}\right]-8 \mathrm{a}$ might be a new probe for PET tumor imaging.
\end{abstract}

\section{Introduction}

Cancer is now not only the leading cause of death, but also a major public health problem all around the world. ${ }^{1}$ The increasing growth and aging of the population are the main factors for the occurrence of cancer, ${ }^{2}$ while in developed countries, it may be induced by a plethora of both external and internal factors. To date, many anticancer drugs have been marketed. The most well-known and widely clinical used type of anticancer agents is nitrogen mustard (nonspecific bifunctional DNA-alkylating agents), which has a serious drawback in that it could cause DNA damage by interrupting DNA biosynthesis. Melphalan, chlorambucil, cyclophosphamide, and bendamustine are revolutionary discoveries in the treatment of cancers. However, many drawbacks exist in these derivatives such as low specificity to tumor cells, eventual loss in activity, high chemical reactivity, and bone-marrow toxicity. ${ }^{3}$ Therefore, the development of novel anticancer drugs with high specificity, activity retention, and low chemical reactivity as well as no bonemarrow toxicity is of great emergency.

Focal adhesion kinase (FAK) is a multi-domain non-receptor tyrosine kinase and scaffold protein localized to focal adhesions, ${ }^{4}$ which is uniquely positioned at the convergence point of

Key Laboratory of Radiopharmaceuticals of Ministry of Education, College of Chemistry, Beijing Normal University, No. 19 Xinjiekouwai Street, Haidian District, Beijing 100875, People's Republic of China.E-mail: hbzhang@bnu.edu.cn

$\dagger$ Electronic supplementary information (ESI) available. See DOI: $10.1039 / \mathrm{c} 6 \mathrm{ra} 28851 \mathrm{k}$ integrins and receptor tyrosine kinase signal transduction pathways, transmitting signals from the extracellular matrix (ECM) to the cell cytoskeleton. A variety of diseases have been identified to be related with FAK, especially cancers, in which FAK is highly expressed or over-expressed at both the transcriptional and translational level. FAK signaling pathways can stimulate tumor progression and metastasis through the regulation of cell migration, invasion, ECM, and angiogenesis. ${ }^{5-7}$ Thus, this protein has emerged as a promising therapeutic target, ${ }^{\mathbf{8}}$ and efforts to investigate FAK for an anticancer effect are under intense investigation. ${ }^{9}$ Accordingly, the inhibition against FAK is considered as an effective antineoplastic strategy by inducing apoptosis and sensitizing tumor cells to chemotherapy. ${ }^{\mathbf{1 0 , 1 1}}$

TAE-226, PF-562271, and PF-573228 are the classical FAK inhibitors. TAE-226 is a novel low-molecular-weight ATPcompetitive tyrosine kinase inhibitor targeting FAK with potent and selective in vitro activity $\left(\mathrm{IC}_{50}=5.5 \mathrm{nM}\right)$. It could inhibit the phosphorylation of FAK, the downstream oncogenic signals, the extracellular signal-related kinase, and the S6 ribosomal protein. ${ }^{12}$ TAE-226 shows impressive antitumor activity against various cancers, such as neuroblastoma, ${ }^{13}$ breast cancer, ${ }^{\mathbf{1 4 , 1 5}}$ and ovarian cancer. ${ }^{\mathbf{1 6}}$ However, the development of TAE-226 has been discontinued in the preclinical stage due to its severe effects on glucose metabolism in animal studies and its inhibition of insulin activity $\left(\mathrm{IC}_{50}=44 \mathrm{nM}\right) .{ }^{17} \mathrm{PF}-562271$, developed by Pfizer, is a dual FAK/Pyk2 inhibitor, and is identified as the first-in-class and first-in-human FAK inhibitor (FAK $\mathrm{IC}_{50}=1.5 \mathrm{nM}$, PYK2 $\mathrm{IC}_{50}=14 \mathrm{nM}$ ) being evaluated in the clinic. 
PF-573228 is another novel small molecule FAK inhibitor that interacts with FAK in the ATP-binding pocket and blocks the catalytic activity of recombinant FAK protein or endogenous FAK. The treatment of cells with PF-573228 blocks FAK phosphorylation on Tyr397 and concomitantly reduces the tyrosine phosphorylation of paxillin. PF-573228 provides an appropriate tool to dissect the role of FAK in the regulation of cell adhesion signaling and adhesion dynamics. ${ }^{18}$

From the above three FAK inhibitors, it can be seen that the same structural feature is the pyrimidine ring, which attracts our intensive interest in studying pyrimidine derivatives as novel FAK inhibitors related to cancers. As we know, the pyrimidine ring is a cyclic amine with two nitrogen atoms. It is the main component of many heterocyclic compounds and plays important roles in many biological processes, such as the synthesis and function of nucleic acids, several vitamins, coenzymes, and purines, etc. ${ }^{\mathbf{1 9 , 2 0}}$ Pyrimidines and their derivatives exhibit a broad spectrum of biological activities including significant in vitro activity against DNA and RNA, potential inhibition property against polio herpes viruses, and as antitumor, anti-HIV, antimicrobial, insecticidal, and antiviral agents..$^{21,22}$

In view of the above observations, a series of novel pyrimidine derivatives as FAK-targeted tumor imaging agents were designed based on the following considerations:

(1) The key framework structure of TAE-226, PF-562271, and PF-573228 should remain as in Fig. 1 to keep the excellent inhibitory activity against FAK. While the strong electronwithdrawing chloro and trifluoromethyl groups are changed into a bromo moiety to explore the effects of electron density at the frame structure on the bioactivity.

(2) The literature has reported that the aliphatic chain is usually considered to be a good substituent to regulate the solubility of target compounds. Given this, aliphatic chains at different lengths are introduced into the phenyl ring at the 2position of pyrimidine ring in order to investigate the physicochemical characters of the designed compounds on the ability against FAK.

(3) To get relatively comprehensive good structure-activity relationships of the target compounds, another phenyl ring is modified by an electron-withdrawing or electron-donating group at different positions, such as methoxyl and carboxyl moieties (Fig. 2).

To make this design more rational, molecular docking between the title compounds and FAK was carried out first (see ESI $\dagger$ ). The total score of compound 8a was demonstrated to be 6.04, and it could form two hydrogen bonds with the FAK residues GLU430 and CYS502 through the $\mathrm{O}$ and $\mathrm{N}$ atoms,

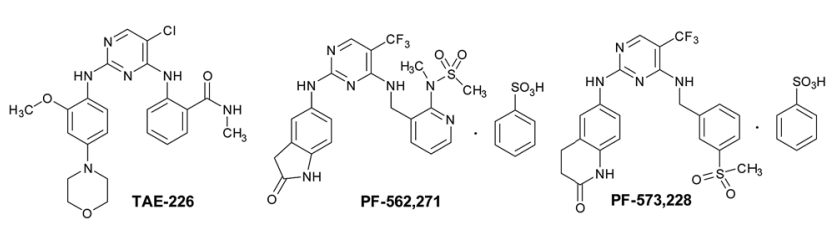

Fig. 1 The structures of some classical FAK inhibitors.

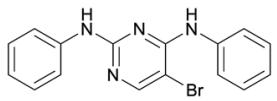

Fig. 2 The key framework structure of the designed novel FAK inhibitors.

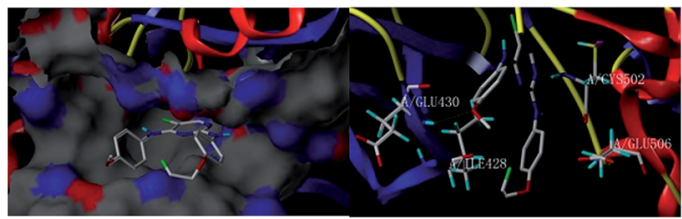

Fig. 3 Molecular docking of compound 8a with FAK (PDB code 4c7t): (left) the lowest energy binding modes; (right) hydrogen bond interactions.

which motivates our interest in further investigating its potentiality as a small molecular antitumor-agent targeting FAK (Fig. 3).

The noninvasive imaging of FAK by positron emission tomography (PET) has the ability to not only provide an innovative pharmacological approach for the diagnosis of diseases but can also contribute to a better understanding of the physiological and pathophysiological functions of FAK. ${ }^{23}{ }^{18} \mathrm{~F}$ is the most favorable positron emission isotope out of all the commonly used ones, which is mainly due to its longer physical half-life of $110 \mathrm{~min}$, its comparable size to the $\mathrm{H}$ atom, and its lower positron energy. ${ }^{24}$ However, until now, only a few research studies on ${ }^{18} \mathrm{~F}$-labeled FAK imaging agents have been reported. Therefore, there is still a need to develop an ${ }^{18} \mathrm{~F}$-labeled FAK imaging agent with high effect and low toxicity, and for providing useful diagnostic tools to investigate diseases related to FAK, including cancer. ${ }^{25}$

In this paper, all the newly synthesized compounds were evaluated for their in vitro inhibitory activity against FAK, and some target compounds were radiolabeled by ${ }^{18} \mathrm{~F}$. The radioactive pyrimidine derivatives were further investigated via partition coefficients determination, in vitro stability studies, and in vivo biodistribution studies in S180-bearing mice to better support their potency as PET imaging agents for cancer detection. Importantly, microPET imaging was also studied to develop new F-18 labeled PET imaging agents based on pyrimidine derivatives.

\section{Experimental}

\section{General methods}

All the chemicals and reagents used in the study were of commercial quality and were used as purchased. Proton nuclear magnetic resonance $\left({ }^{1} \mathrm{H}\right.$ NMR) spectra were acquired using a BRUKER AVANCE® III HD 400 Spectrometer in $\mathrm{CDCl}_{3}$ solutions at room temperature. Chemical shifts were given in chemical shift $(\delta)$ as parts per million (ppm) relative to tetramethylsilane (TMS), which was used as an internal standard, and were referenced to the centerline of deuterochloroform 
(7.27 $\mathrm{ppm}{ }^{1} \mathrm{H}$ NMR). The ESI-MS spectra were determined on a Waters Quattro Micro® Quadrupole Mass Spectrometer. Thin layer chromatography was performed on glass plates coated with $60 \mathrm{GF}_{254}$ silica. Plates were visualized using UV light (254 $\mathrm{nm}$ ). Flash column chromatography was carried out using an Interchim Puriflash ${ }^{\circledR} 4100$ medium pressure preparative chromatography apparatus on silica gel (Bonna-Agela ${ }^{\circledR}$ flash silica, 40-60 $\mu \mathrm{m}, 60 \AA$ ).

Truncated human FAK(PTK2) [376-1052(end) amino acids of accession number NP_722560.1] was provided by Carna Biosciences, Inc. The HTRF KinEASE®-TK kit was purchased from Cisbio Biosciences, Inc.

The $\left[{ }^{18} \mathrm{~F}\right]$ fluoride used for the radiosynthesis was produced by the ${ }^{18} \mathrm{O}(\mathrm{p}, \mathrm{n}){ }^{18} \mathrm{~F}$ nuclear reaction by irradiation on $97 \%$ enriched $\mathrm{H}_{2}{ }^{18} \mathrm{O}$ at the Nuclear Medicine Department of Peking Cancer Hospital (Beijing, China). QMA light ion-exchange cartridges and C-18 light Sep-Pak ${ }^{\circledR}$ cartridges were obtained from Waters (Milford, MA). We activated the Waters Sep-Pak® Accell $^{\text {тм }}$ Plus QMA Plus Light Cartridges (130 mg sorbent per cartridge, 37-55 $\mu \mathrm{m}$ particle size) with $1 \mathrm{~N} \mathrm{NaHCO}_{3}(10 \mathrm{~mL})$, followed by deionized water $(10 \mathrm{~mL})$, and the Waters Sep-Pak® C18 Plus Light Cartridges (130 mg sorbent per cartridge, 55-105 $\mu \mathrm{m}$ particle size) with methanol $(10 \mathrm{~mL})$ and deionized water $(10 \mathrm{~mL})$ before use. Radiopharmaceuticals were purified and their radiochemical purity were determined on a Shimadzu® LC-20AT HPLC apparatus equipped with a SPD-20A UV detector $(\lambda=254 \mathrm{~nm})$ and Bioscan ${ }^{\circledR}$ flow count $3200 \mathrm{NaI} / \mathrm{PMT} \gamma$-radiation scintillation detector. We performed the radiopharmaceutical HPLC separations on an Inertsil@ ODS-3 C18 reverse phase semi-preparative column (GL Sciences, Inc. $5 \mu \mathrm{m}, 10 \mathrm{~mm} \times 250$ $\mathrm{mm}$ ), and we carried out the elution with a binary gradient

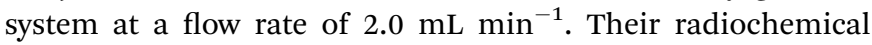
purity determinations were achieved on a Kromasil@ 100-5C18 reverse phase column (AkzoNobel, $5 \mu \mathrm{m}, 4.6 \mathrm{~mm} \times 250 \mathrm{~mm}$ ), and elution was carried out with a binary gradient system at

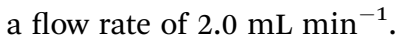

S180 ascites sarcoma mice were purchased from Beijing Vitalriver Animal Technology Co., Ltd, and normal ICR mice (20$25 \mathrm{~g}$, female) were provided by Beijing Xinglong Animal Technology Co., Ltd. ${ }^{18} \mathrm{~F}$ radioactivity of the tissues and organs of interest was measured on a PerkinElmer® 2480 WIZARD $^{2}$ automatic gamma counter. The microPET imaging was performed on a SuperArgus PET/CT, which was designed and manufactured by SEDECAL (Sociedad Española de Electromedicina y Calidad, S.A.). All the protocols requiring the use of mice were in accordance with the "guidelines for humane treatment of laboratory animals" promulgated by the National Health and Family Planning Commission of China, and were approved by the Animal Care Committee of Beijing Normal University.

\section{Synthesis of intermediate 2}

A mixture of ethane-1,2-diyl bis(4-methylbenzenesulfonate) (13.58 g, $36.66 \mathrm{mmol}, 1.5$ equiv.), $\mathrm{K}_{2} \mathrm{CO}_{3}(12.67 \mathrm{~g}, 91.65 \mathrm{mmol}$, 3.75 equiv.) and 18-crown-6 (0.32 g, $1.22 \mathrm{mmol}, 0.05$ equiv.) was added to a solution of $1(3.40 \mathrm{~g}, 24.41 \mathrm{mmol})$ in acetone $(30 \mathrm{~mL})$. After stirring at $56^{\circ} \mathrm{C}$ for $3-4 \mathrm{~h}$ (TLC monitoring showed that the raw material of $\mathbf{1}$ was completely consumed by that time), the reaction mixture was filtered, and the filtrate was concentrated in vacuo. The residue was purified by column chromatography (dichloromethane to dichloromethane/MeOH, 100/1) (Caution! Using petroleum ether/AcOEt as the eluent would cause the crystallization of the product in the column, leading to blocking of the column!) to give relatively pure intermediate 2 as a light yellow solid (2.94 g). (Note: a small part of the superfluous raw material TsO- $\mathrm{CH}_{2}-\mathrm{CH}_{2}-\mathrm{OTs}$ was included and was unable to be completely separated from the intermediate 2 , since the polarity of the raw material TsO- $\mathrm{CH}_{2}-\mathrm{CH}_{2}-\mathrm{OTs}$ was close to that of the intermediate 2 . Therefore, the ${ }^{1} \mathrm{H}$ NMR analysis was not performed in this step of the reaction. However, the remaining raw material TsO- $\mathrm{CH}_{2}-\mathrm{CH}_{2}-\mathrm{OTs}$ included in the relatively pure intermediate 2 had little effect on the next step of reaction, and the mole of 2 used in the next step of the reaction was calculated as the hypothetical mass of pure 2 divided by the relative molecular mass of 2.)

\section{Synthesis of intermediate 3}

To a solution of $2(2.94 \mathrm{~g}, 8.71 \mathrm{mmol})$ in dichloromethane (15 $\mathrm{mL})$ and glacial acetic acid $(15 \mathrm{~mL})$ was added zinc powder (2.83 g, $43.57 \mathrm{mmol})$. The mixture was stirred at ambient temperature for $12 \mathrm{~h}$ under an inert atmosphere. The reaction mixture was filtered, and the filtrate was concentrated in vacuo. The crude intermediate $3(2.02 \mathrm{~g})$ was immediately used for the next step of the reaction without further purification since the intermediate 3 was unstable in air. However, according to the immediate ESI-MS analysis of the reaction mixture, we could obviously find the characteristic peak of 3: $308.2\left(\mathrm{C}_{15} \mathrm{H}_{18} \mathrm{NO}_{4} \mathrm{~S}\right.$, $\left.[\mathrm{M}+\mathrm{H}]^{+}\right), 330.1\left(\mathrm{C}_{15} \mathrm{H}_{17} \mathrm{NO}_{4} \mathrm{SNa},[\mathrm{M}+\mathrm{Na}]^{+}\right)$. Furthermore, the mole of 3 used in the next step of the reaction was also calculated as the hypothetical mass of pure 3 divided by the relative molecular mass of 3 .

\section{Synthesis of intermediate $6 a$}

Here, 4-methoxyphenyl amine (150 mmol) was added to a solution of 5-bromo-2,4-dichloropyrimidine 4 (100 $\mathrm{mmol})$ in i-PrOH $(200 \mathrm{~mL})$ at ambient temperature. The first batch of the precipitant appeared after a few minutes of stirring at room temperature. After filtration, to the filtrate was added the solution of $\mathrm{K}_{2} \mathrm{CO}_{3}(300 \mathrm{mmol})$ in water $(200 \mathrm{~mL})$, and the reaction mixture was stirred at room temperature until all of the 5-bromo-2,4dichloropyrimidine $\mathbf{4}$ was consumed completely, as shown by TLC monitoring. The resulting second batch of the precipitant was filtered and the filter cake was washed with water and ethyl acetate in sequence. After desiccation, the two batches of precipitant were combined to give the 5-bromo-2-chloro- $\mathrm{N}$ phenylpyrimidin-4-amines $6 \mathrm{a}$ as a gray solid $(16.17 \mathrm{~g}, 51.4 \%) .{ }^{1} \mathrm{H}$ NMR (400 MHz, $\left.\mathrm{CDCl}_{3}, \delta \mathrm{ppm}\right): 8.25$ (s, 1H), 7.47 (d, $J=8.0 \mathrm{~Hz}$, 2H), $7.16(\mathrm{br}, 1 \mathrm{H}), 6.93(\mathrm{~d}, J=8.0 \mathrm{~Hz}, 2 \mathrm{H}), 3.83$ (s, 3H). ESI-MS: calcd for $\mathrm{C}_{11} \mathrm{H}_{10} \mathrm{BrClN}_{3} \mathrm{O}\left([\mathrm{M}+\mathrm{H}]^{+}\right)$314.0, found $314.3\left([\mathrm{M}+\mathrm{H}]^{+}\right)$.

\section{Synthesis of intermediate $6 b$}

A similar reaction to that described above to prepare 6a was used to obtain $6 \mathbf{b}$ as a gray solid $(4.9 \mathrm{~g}, 55 \%) .{ }^{1} \mathrm{H} \mathrm{NMR}(400 \mathrm{MHz}$, 
DMSO-d $\left._{6}\right) \delta: 3.66(\mathrm{~s}, 3 \mathrm{H}), 3.76(\mathrm{~s}, 6 \mathrm{H}), 7.01(\mathrm{~s}, 1 \mathrm{H}), 8.45(\mathrm{~s}, 1 \mathrm{H})$, 9.18 (s, br, $1 \mathrm{H})$. ESI-MS: calcd for $\mathrm{C}_{13} \mathrm{H}_{14} \operatorname{BrClN}_{3} \mathrm{O}_{3}\left([\mathrm{M}+\mathrm{H}]^{+}\right)$ 374.0, found $373.9\left([\mathrm{M}+\mathrm{H}]^{+}\right)$.

\section{Synthesis of intermediate $6 \mathrm{c}$}

A similar reaction to that described above to prepare $6 \mathbf{a}$ was used to obtain $6 \mathrm{c}$ as a white solid $(3.5 \mathrm{~g}, 49 \%) .{ }^{1} \mathrm{H}$ NMR $(400$ MHz, DMSO-d $\left.{ }_{6}\right) \delta: 7.74(\mathrm{~d}, J=8.4 \mathrm{~Hz}, 2 \mathrm{H}), 7.83(\mathrm{~d}, J=8.8 \mathrm{~Hz}$, $2 \mathrm{H}), 8.55(\mathrm{~s}, 1 \mathrm{H}), 9.55(\mathrm{~s}, \mathrm{br}, 1 \mathrm{H})$. ESI-MS: calcd for $\mathrm{C}_{11} \mathrm{H}_{7^{-}}$ $\mathrm{BrClF}_{3} \mathrm{~N}_{3}\left([\mathrm{M}+\mathrm{H}]^{+}\right)$351.9, found $352.1\left([\mathrm{M}+\mathrm{H}]^{+}\right)$.

\section{Synthesis of intermediate $6 \mathrm{~d}$}

A similar reaction to that described above to prepare $6 \mathbf{a}$ was used to obtain $\mathbf{6 d}$ as a light yellow solid (3.8 g, 54\%). ${ }^{1} \mathrm{H}$ NMR $\left(400 \mathrm{MHz}, \mathrm{DMSO}_{\mathrm{d}}\right.$ ) $\delta: 9.51$ (s, br, $\left.1 \mathrm{H}\right), 8.42(\mathrm{~s}, 1 \mathrm{H}), 7.92$ (d, $J=$ $8.4 \mathrm{~Hz}, 2 \mathrm{H}), 7.67$ (d, $J=8.8 \mathrm{~Hz}, 2 \mathrm{H}), 4.29$ (q, $J=6.8 \mathrm{~Hz}, 2 \mathrm{H}), 1.32$ $(\mathrm{t}, J=6.8 \mathrm{~Hz}, 3 \mathrm{H})$. ESI-MS: calcd for $\mathrm{C}_{13} \mathrm{H}_{12} \mathrm{BrClN}_{3} \mathrm{O}_{2}\left([\mathrm{M}+\mathrm{H}]^{+}\right)$ 356.0, found $356.1\left([\mathrm{M}+\mathrm{H}]^{+}\right)$.

\section{Synthesis of intermediate 10a}

TBAF (36 mL, $1 \mathrm{M}$ in THF) was added to a solution of ethylene di(p-toluenesulfonate), 9a (11.1 g, $30 \mathrm{mmol})$, and $80 \mathrm{~mL}$ THF with stirring. The mixture was refluxed overnight and the solvent was removed under reduced pressure. The residue was partitioned between water and ethyl acetate. The organic phase was dried over anhydrous sodium sulfate and filtered. After concentration, the crude product was purified via silica gel column chromatography by eluting with ethyl acetate/hexane $(1 / 5, \mathrm{v} / \mathrm{v})$ to give 10a as a slightly yellow oil (3.27 $\mathrm{g}, 50 \%$ yield). ${ }^{1} \mathrm{H} \mathrm{NMR}\left(300 \mathrm{MHz}, \mathrm{CDCl}_{3}\right): \delta 7.85(\mathrm{~d}, J=8.2 \mathrm{~Hz}, 2 \mathrm{H}), 7.40(\mathrm{~d}, J=$ $8.2 \mathrm{~Hz}, 2 \mathrm{H}), 2.49(\mathrm{~s}, 3 \mathrm{H}), 4.69(\mathrm{t}, J=4.5 \mathrm{~Hz}, 1 \mathrm{H}), 4.53(\mathrm{t}, J=$ $4.5 \mathrm{~Hz}, 1 \mathrm{H}), 4.35(\mathrm{t}, J=4.5 \mathrm{~Hz}, 1 \mathrm{H}), 4.26(\mathrm{t}, J=4.2 \mathrm{~Hz}, 1 \mathrm{H})$ (the ${ }^{1} \mathrm{H}$ NMR data of 10a were identical with those in the literature $\left.{ }^{26}\right)$.

\section{Synthesis of intermediate $10 \mathrm{~b}$}

10b was prepared from $9 b(10.25 \mathrm{~g}, 24.7 \mathrm{mmol})$ as described above for 10a. The crude product was purified by silica gel column chromatography by eluting with ethyl acetate/hexane $(3 / 10, v / v)$ to give $10 \mathrm{~b}$ as a colorless oil $(2.66 \mathrm{~g}, 41 \%$ yield $) .{ }^{1} \mathrm{H}$ NMR (300 MHz, $\left.\mathrm{CDCl}_{3}\right): \delta 7.81(\mathrm{~d}, J=8.1 \mathrm{~Hz}, 2 \mathrm{H}), 7.35(\mathrm{~d}, J=$ $8.1 \mathrm{~Hz}, 2 \mathrm{H}), 4.57(\mathrm{t}, J=4.2 \mathrm{~Hz}, 1 \mathrm{H}), 4.41(\mathrm{t}, J=4.2 \mathrm{~Hz}, 1 \mathrm{H}), 4.18$ $(\mathrm{t}, J=4.8 \mathrm{~Hz}, 2 \mathrm{H}), 3.69-3.76(\mathrm{~m}, 3 \mathrm{H}), 3.63(\mathrm{t}, J=4.2 \mathrm{~Hz}, 1 \mathrm{H}), 2.45$ $(\mathrm{s}, 3 \mathrm{H})$ (the ${ }^{1} \mathrm{H}$ NMR data of $\mathbf{1 0 b}$ were identical with those in the literature $\left.{ }^{26}\right)$.

\section{Synthesis of intermediate 14a}

Briefly, to a mixture of 13a (124 g, $2 \mathrm{~mol}$ ) and triethylamine $(12 \mathrm{~g}, 0.12 \mathrm{~mol})$ in dry DCM $(100 \mathrm{~mL})$ was added TsCl $(19 \mathrm{~g}, 0.1$ $\mathrm{mol})$ in dry DCM $(100 \mathrm{~mL})$ dropwise at $0{ }^{\circ} \mathrm{C}$. The solution was stirred at $0{ }^{\circ} \mathrm{C}$ for $3 \mathrm{~h}$. Then, the reaction was quenched with water. After extraction with DCM, the organic phase was washed with water two times. After removal of the solvent, the residue was purified by silica gel chromatography to give $14 a(12 \mathrm{~g}$, $37.1 \%$ ) as a colorless oil. ${ }^{1} \mathrm{H} \mathrm{NMR}\left(400 \mathrm{MHz}, \mathrm{CDCl}_{3}\right): \delta 7.81$ (d, $2 \mathrm{H}, J=8.0 \mathrm{~Hz}), 7.35(\mathrm{~d}, 2 \mathrm{H}, J=8.0 \mathrm{~Hz}), 4.15(\mathrm{t}, 2 \mathrm{H}, J=4.0 \mathrm{~Hz})$,
3.66-3.71 (m, 2H), $2.45(\mathrm{~s}, 3 \mathrm{H})$ (the ${ }^{1} \mathrm{H}$ NMR data of 14a were identical with those in the literature $\left.{ }^{27}\right)$.

\section{Synthesis of intermediate $14 \mathrm{~b}$}

A similar reaction to that described above to prepare 14a was used to obtain 14b as a colorless oil (15 g, 58\%). ${ }^{1} \mathrm{H}$ NMR (400 $\left.\mathrm{MHz}, \mathrm{CDCl}_{3}\right): \delta 7.80(\mathrm{~d}, 2 \mathrm{H}, J=7.8 \mathrm{~Hz}), 7.35(\mathrm{~d}, 2 \mathrm{H}, J=7.8 \mathrm{~Hz})$, $4.20(\mathrm{t}, 2 \mathrm{H}, J=4.0 \mathrm{~Hz}), 3.66-3.71(\mathrm{~m}, 4 \mathrm{H}), 3.52-3.55(\mathrm{~m}, 2 \mathrm{H})$, $2.45(\mathrm{~s}, 3 \mathrm{H})$ (the ${ }^{1} \mathrm{H}$ NMR data of $\mathbf{1 4 b}$ were identical with those in the literature $\left.{ }^{28}\right)$.

\section{Synthesis of intermediate $15 \mathrm{a}$}

A mixture of 14a (12 g, $0.056 \mathrm{~mol}$ ), 4-nitrophenol (9.3 g, 0.067 $\mathrm{mol}$ ), and $\mathrm{K}_{2} \mathrm{CO}_{3}(13.8 \mathrm{~g}, 0.1 \mathrm{~mol})$ in DMF (50 mL) was heated at $75{ }^{\circ} \mathrm{C}$ overnight. The mixture was filtered and the filtrate was concentrated in vacuo. The residue was recrystallized from methanol to give $15 a(4.5 \mathrm{~g}, 14 \%)$ as a light yellow solid. ${ }^{1} \mathrm{H}$ NMR $\left(\mathrm{CDCl}_{3}\right): \delta 8.10(\mathrm{~d}, 2 \mathrm{H}, J=8.0 \mathrm{~Hz}), 7.01-7.06(\mathrm{~m}, 2 \mathrm{H}), 4.09-4.14$ $(\mathrm{m}, 2 \mathrm{H}), 3.89-3.92(\mathrm{~m}, 2 \mathrm{H})$ (the ${ }^{1} \mathrm{H}$ NMR data of 15a were identical with those in the literature ${ }^{29}$ ).

\section{Synthesis of intermediate $15 b$}

A similar reaction to that described above to prepare 15a was used to obtain $\mathbf{1 5 b}$ as a light yellow solid $(10 \mathrm{~g}, 76 \%) .{ }^{1} \mathrm{H}$ NMR $\left(\mathrm{CDCl}_{3}\right): \delta 8.10(\mathrm{~d}, 2 \mathrm{H}, J=8.0 \mathrm{~Hz}), 7.01-7.06(\mathrm{~m}, 2 \mathrm{H}), 4.09-4.14$ $(\mathrm{m}, 2 \mathrm{H}), 3.89-3.92(\mathrm{~m}, 4 \mathrm{H}), 3.75-3.78(\mathrm{~m}, 2 \mathrm{H})$ (the ${ }^{1} \mathrm{H}$ NMR data of $\mathbf{1 5 b}$ were identical with those in the literature $\left.{ }^{30}\right)$.

\section{Synthesis of intermediate 11a}

A similar reaction to that described above to prepare 15a was used to obtain 11a as a light yellow solid (9 g, 74\%). ${ }^{1} \mathrm{H}$ NMR $\left(400 \mathrm{MHz}, \mathrm{CDCl}_{3}\right): \delta 8.23\left(\mathrm{~d}, 2 \mathrm{H},{ }^{3} J=9.0 \mathrm{~Hz}\right), 7.00\left(\mathrm{~d}, 2 \mathrm{H},{ }^{3} J=9.0\right.$ $\mathrm{Hz}), 4.80\left(\mathrm{dt}, 2 \mathrm{H},{ }^{3} J_{\mathrm{H}-\mathrm{H}}=4.4 \mathrm{~Hz},{ }^{2} J_{\mathrm{H}-\mathrm{F}}=47.6 \mathrm{~Hz}\right), 4.32(\mathrm{dt}, 2 \mathrm{H}$, ${ }^{3} J_{\mathrm{H}-\mathrm{H}}=4.0 \mathrm{~Hz},{ }^{3} J_{\mathrm{H}-\mathrm{F}}=27.6 \mathrm{~Hz}$ ) (the ${ }^{1} \mathrm{H}$ NMR data of 11a were identical with those in the literature ${ }^{31}$ ).

\section{Synthesis of intermediate 12a}

A similar reaction to that described above to prepare 15a was used to obtain 12a as a light yellow solid (7.5 g, 68\%). ${ }^{1} \mathrm{H}$ NMR $\left(300 \mathrm{MHz}, \mathrm{CDCl}_{3}\right): \delta 4.141(\mathrm{dt}, J=1.0 \mathrm{~Hz}, J=1.0 \mathrm{~Hz}, 2 \mathrm{H}), 4.715$ $(\mathrm{dt}, J=2.0 \mathrm{~Hz}, J=1.0 \mathrm{~Hz}, 2 \mathrm{H}), 6.650(\mathrm{~d}, J=2.0 \mathrm{~Hz}, 2 \mathrm{H}), 6.771$ (d, $J=2.0 \mathrm{~Hz}, 2 \mathrm{H}$ ) (the ${ }^{1} \mathrm{H}$ NMR data of $11 \mathrm{a}$ were identical with those in the literature ${ }^{32}$ ).

\section{Synthesis of intermediate 16a}

A mixture of 15a $(4.5 \mathrm{~g}, 25 \mathrm{mmol})$ and $7.5 \% \mathrm{Pd} / \mathrm{C}(0.45 \mathrm{~g})$ in ethanol $(50 \mathrm{~mL})$ was stirred under a $\mathrm{H}_{2}$ atmosphere for $5 \mathrm{~h}$. The mixture was filtered and the filtrate was concentrated in vacuo. The crude 16a (2.6 g) was used in the next step without further purification since the intermediate 16a was unstable in air. Furthermore, the mole of 16a used in the next step of the reaction was also calculated as the hypothetical mass of pure 16a divided by the relative molecular mass of $\mathbf{1 6 a}$. 


\section{Synthesis of intermediate 16b}

A similar reaction to that described above to prepare 16a was used to obtain the crude $\mathbf{1 6 b}$ as a red oil (3.2 g), which was then used in the next step without further purification since the intermediate $\mathbf{1 6 b}$ was unstable in air. Furthermore, the mole of 16b used in the next step of the reaction was also calculated as the hypothetical mass of pure $\mathbf{1 6 b}$ divided by the relative molecular mass of $\mathbf{1 6 b}$.

\section{Synthesis of intermediate 12a}

A similar reaction to that described above to prepare 16a was used to obtain the crude $12 \mathrm{a}$ as a red oil (5.4 g), which was then used in the next step without further purification since the intermediate 12a was unstable in air. Furthermore, the mole of 12a used in the next step of the reaction was also calculated as the hypothetical mass of pure 12a divided by the relative molecular mass of $\mathbf{1 2 a}$.

\section{Synthesis of intermediate $12 b$}

A similar reaction to that described above to prepare 16a was used to obtain the crude $\mathbf{1 2 b}$ as a red oil (4.1 g), which was then used in the next step without further purification since the intermediate 12b was unstable in air. Furthermore, the mole of 12b used in the next step of the reaction was also calculated as the hypothetical mass of pure $\mathbf{1 2 b}$ divided by the relative molecular mass of $\mathbf{1 2 b}$.

\section{Synthesis of precursor 7}

A mixture of the crude compound $3(0.91 \mathrm{~g}, 3.0 \mathrm{mmol})$ and intermediate $6 \mathbf{a}(0.62 \mathrm{~g}, 2.0 \mathrm{mmol})$ in 1,4-dioxane $(20 \mathrm{~mL})$ using $p$-toluenesulfonic acid $(0.14 \mathrm{~g}, 0.8 \mathrm{mmol})$ as the catalyst was stirred under reflux under an inert atmosphere. When intermediate 6a was completely consumed (as monitored by TLC, petroleum ether/ethyl acetate, $3 / 1, \mathrm{v} / \mathrm{v}$ ), it was concentrated under reduced pressure. The resulting residue was purified by silica gel column chromatography by eluting with petroleum ether/ethyl acetate $(6 / 1-2 / 1, v / v)$ to give the pure compound 7 (60 $\mathrm{mg}$ ) with the yield of $5.2 \%$. ${ }^{1} \mathrm{H} \mathrm{NMR}\left(400 \mathrm{MHz} \mathrm{CDCl}_{3}, \delta \mathrm{ppm}\right)$ : $7.94(\mathrm{~s}, 1 \mathrm{H}), 7.81(\mathrm{~d}, J=8.3 \mathrm{~Hz}, 4 \mathrm{H}), 7.30-7.40(\mathrm{~m}, 8 \mathrm{H}), 4.36(\mathrm{t}, J$ $=4.7 \mathrm{~Hz}, 2 \mathrm{H}), 4.13(\mathrm{t}, J=4.5 \mathrm{~Hz}, 2 \mathrm{H}), 3.86(\mathrm{~s}, 3 \mathrm{H}), 2.44(\mathrm{~s}, 3 \mathrm{H})$; ${ }^{13} \mathrm{C}$ NMR (100 MHz, DMSO-d 6 , $\delta$ ppm): 158.71, 157.92, 157.24, 153.07, 153.00, 145.52, 135.06, 134.70, 132.79, 130.65, 128.17, 124.87, 121.18, 116.73, 114.77, 92.81, 69.70, 66.12, 55.65, 21.58; HRMS (ESI): calcd for $\mathrm{C}_{26} \mathrm{H}_{26} \mathrm{BrN}_{4} \mathrm{O}_{5} \mathrm{~S}\left([\mathrm{M}+\mathrm{H}]^{+}\right)$585.0729, found $585.0713\left([\mathrm{M}+\mathrm{H}]^{+}\right)$.

\section{Synthesis of intermediate 17a}

A similar reaction to that described above to prepare 7 was used to obtain the crude $17 \mathrm{a}(0.57 \mathrm{~g})$, which was then used in the next step without further purification since the intermediate 17a was unstable in air. Furthermore, the mole of the 17a used in the next step of the reaction was also calculated as the hypothetical mass of pure 17a divided by the relative molecular mass of 17a.

\section{Synthesis of intermediate $17 \mathrm{~b}$}

A similar reaction to that described above to prepare 7 was used to obtain the crude $17 \mathbf{b}(0.62 \mathrm{~g})$, which was then used in the next step without further purification since the intermediate $\mathbf{1 7 b}$ was unstable in air. Furthermore, the mole of the $\mathbf{1 7 \mathbf { b }}$ used in the next step of the reaction was also calculated as the hypothetical mass of pure $\mathbf{1 7} \mathbf{b}$ divided by the relative molecular mass of $\mathbf{1 7} \mathbf{b}$.

\section{Synthesis of intermediate $17 \mathrm{c}$}

A similar reaction to that described above to prepare 7 was used to obtain the crude $17 \mathrm{c}(0.65 \mathrm{~g})$, which was then used in the next step without further purification since the intermediate $17 \mathbf{c}$ was unstable in air. Furthermore, the mole of $17 \mathbf{c}$ used in the next step of reaction was also calculated as the hypothetical mass of pure $17 \mathrm{c}$ divided by the relative molecular mass of $17 \mathrm{c}$.

\section{Synthesis of intermediate 17d}

A similar reaction to that described above to prepare 7 was used to obtain the crude $17 \mathrm{~d}(0.64 \mathrm{~g})$, which was then used in the next step without further purification since the intermediate $17 \mathbf{d}$ was unstable in air. Furthermore, the mole of 17d used in the next step of the reaction was also calculated as the hypothetical mass of pure $\mathbf{1 7 d}$ divided by the relative molecular mass of $\mathbf{1 7 d}$.

\section{Synthesis of intermediate $17 \mathrm{e}$}

A similar reaction to that described above to prepare 7 was used to obtain the crude $17 \mathrm{e}(0.72 \mathrm{~g})$, which was then used in the next step without further purification since the intermediate 17e was unstable in air. Furthermore, the mole of 17e used in the next step of the reaction was also calculated as the hypothetical mass of pure 17e divided by the relative molecular mass of $17 \mathrm{e}$.

\section{Synthesis of intermediate $17 f$}

A similar reaction to that described above to prepare 7 was used to obtain the crude $\mathbf{1 7 f}(0.69 \mathrm{~g})$, which was then used in the next step without further purification since the intermediate $\mathbf{1 7 f}$ was unstable in air. Furthermore, the mole of $\mathbf{1 7 f}$ used in the next step of the reaction was also calculated as the hypothetical mass of pure $\mathbf{1 7 f}$ divided by the relative molecular mass of $\mathbf{1 7 f}$.

\section{Synthesis of precursor 18a}

Briefly, to a mixture of 17a (570 $\mathrm{mg}, 1.2 \mathrm{mmol})$, triethylamine (202 $\mathrm{mg}, 2 \mathrm{mmol}$ ), and 4-dimethylaminepyridine (14 mg, 0.12 $\mathrm{mmol})$ in dry DCM $(10 \mathrm{~mL})$ was added TsCl $(380 \mathrm{mg}, 2 \mathrm{mmol})$ in dry DCM $(10 \mathrm{~mL})$ dropwise at $0{ }^{\circ} \mathrm{C}$. The solution was stirred at $0{ }^{\circ} \mathrm{C}$ for $3 \mathrm{~h}$. Then, the reaction was quenched with water. After extraction with DCM, the organic phase was washed with water two times. After removal of the solvent, the residue was purified by silica gel chromatography to give $18 \mathrm{a}(0.30 \mathrm{~g}, 45 \%)$ as a red solid. ${ }^{1} \mathrm{H}$ NMR (400 MHz, DMSO-d ${ }_{6}$ ): $\delta 9.18$ (s, br, 1H), $8.48(\mathrm{~s}$, br, $1 \mathrm{H}), 8.16(\mathrm{~s}, 1 \mathrm{H}), 7.79(\mathrm{~d}, J=8.0 \mathrm{~Hz}, 2 \mathrm{H}), 7.47(\mathrm{~d}, J=8.8 \mathrm{~Hz}$, $4 \mathrm{H}), 6.91(\mathrm{~s}, 2 \mathrm{H}), 6.63(\mathrm{~d}, J=9.2 \mathrm{~Hz}, 2 \mathrm{H}), 4.30(\mathrm{~s}, 2 \mathrm{H}), 4.06(\mathrm{~s}$, 2H), 3.67-3.68 (m, 9H), 2.41 (s, 3H); ${ }^{13} \mathrm{C}$ NMR (100 MHz, DMSO$\left.\mathrm{d}_{6}, \delta \mathrm{ppm}\right): 158.71,157.92,157.24,153.07,153.00,145.52$, 
135.06, 134.70, 132.79, 130.65, 128.17, 121.18, 116.73, 114.77, 92.81, 69.70, 66.12, 60.65, 56.22, 21.58; HRMS (ESI): calcd for $\mathrm{C}_{28} \mathrm{H}_{30} \mathrm{BrN}_{4} \mathrm{O}_{7} \mathrm{~S}\left([\mathrm{M}+\mathrm{H}]^{+}\right)$645.0940, found $645.1007\left([\mathrm{M}+\mathrm{H}]^{+}\right)$.

\section{Synthesis of precursor $18 b$}

A similar reaction to that described above to prepare 18a was used to obtain $\mathbf{1 8 b}$ as a light yellow solid $(0.53 \mathrm{~g}, 66 \%) .{ }^{1} \mathrm{H}$ NMR $\left(\right.$ DMSO-d $\left._{6}\right) \delta: 9.26(\mathrm{~s}, \mathrm{br}, 1 \mathrm{H}), 8.86(\mathrm{~s}, \mathrm{br}, 1 \mathrm{H}), 8.26(\mathrm{~s}, 1 \mathrm{H}), 7.89$ $(\mathrm{d}, J=7.6 \mathrm{~Hz}, 2 \mathrm{H}), 7.79(\mathrm{~d}, J=8.0 \mathrm{~Hz}, 2 \mathrm{H}), 7.66(\mathrm{~d}, J=8.4 \mathrm{~Hz}$, $2 \mathrm{H}), 7.43-7.47(\mathrm{~m}, 4 \mathrm{H}), 6.71(\mathrm{~d}, J=8.8 \mathrm{~Hz}, 2 \mathrm{H}), 4.32(\mathrm{t}, J=$ $4.0 \mathrm{~Hz}, 2 \mathrm{H}), 4.10(\mathrm{t}, J=4.0 \mathrm{~Hz}, 2 \mathrm{H}), 2.40(\mathrm{~s}, 3 \mathrm{H}) ;{ }^{13} \mathrm{C} \mathrm{NMR}(100$ MHz, DMSO-d ${ }_{6}, \delta$ ppm): 158.73, 156.82, 153.34, 145.47, 143.25, $134.27,132.79,130.61,128.16,125.87,124.11,124.06,123.85$, 123.09, 121.70, 114.83, 69.67, 66.04, 21.55; HRMS (ESI): calcd for $\mathrm{C}_{26} \mathrm{H}_{23} \mathrm{BrF}_{3} \mathrm{~N}_{4} \mathrm{O}_{4} \mathrm{~S}\left([\mathrm{M}+\mathrm{H}]^{+}\right)$623.0497, found 623.0568 $\left([\mathrm{M}+\mathrm{H}]^{+}\right)$.

\section{Synthesis of precursor $18 \mathrm{c}$}

A similar reaction to that described above to prepare 18a was used to obtain $18 \mathrm{c}$ as a light yellow solid $(0.52 \mathrm{~g}, 60 \%) .{ }^{1} \mathrm{H}$ NMR $\left(\mathrm{DMSO}_{6} \mathrm{~d}_{6}\right) \delta: 9.26(\mathrm{~s}, \mathrm{br}, 1 \mathrm{H}), 8.80(\mathrm{~s}, \mathrm{br}, 1 \mathrm{H}), 8.25(\mathrm{~s}, 1 \mathrm{H}), 7.87-$ $7.90(\mathrm{~m}, 4 \mathrm{H}), 7.79(\mathrm{~d}, J=8.4 \mathrm{~Hz}, 2 \mathrm{H}), 7.46(\mathrm{~d}, J=8.4 \mathrm{~Hz}, 4 \mathrm{H})$, $6.71(\mathrm{~d}, J=8.8 \mathrm{~Hz}, 2 \mathrm{H}), 4.29-4.32(\mathrm{~m}, 4 \mathrm{H}), 4.10-4.11(\mathrm{~m}, 2 \mathrm{H})$, 2.39 (s, 3H), 1.32 (t, $J=7.2 \mathrm{~Hz}, 3 \mathrm{H}) ;{ }^{13} \mathrm{C} \mathrm{NMR}\left(100 \mathrm{MHz}, \mathrm{CDCl}_{3}\right.$, $\delta$ ppm): 166.21, 158.61, 157.15, 155.86, 154.43, 145.05, 142.29, 132.94, 132.69, 130.68, 129.97, 128.14, 125.62, 122.62, 119.97, 115.03, 68.26, 65.92, 61.00, 21.55, 14.50; HRMS (ESI): calcd for $\mathrm{C}_{28} \mathrm{H}_{28} \mathrm{BrN}_{4} \mathrm{O}_{6} \mathrm{~S}\left([\mathrm{M}+\mathrm{H}]^{+}\right)$627.0835, found $627.0901\left([\mathrm{M}+\mathrm{H}]^{+}\right)$.

\section{Synthesis of precursor 18d}

A similar reaction to that described above to prepare 18a was used to obtain $18 d$ as a light yellow solid $(0.52 \mathrm{~g}, 60 \%) .{ }^{1} \mathrm{H}$ NMR $\left(\right.$ DMSO-d $\left._{6}\right) \delta: 9.17(\mathrm{~s}, \mathrm{br}, 1 \mathrm{H}), 8.46(\mathrm{~s}, \mathrm{br}, 1 \mathrm{H}), 8.16(\mathrm{~s}, 1 \mathrm{H}), 7.78$ (d, $J=8.4 \mathrm{~Hz}, 2 \mathrm{H}), 7.49(\mathrm{~d}, J=9.2 \mathrm{~Hz}, 2 \mathrm{H}), 7.44(\mathrm{~d}, J=8.0 \mathrm{~Hz}$, $2 \mathrm{H}), 6.91(\mathrm{~s}, 2 \mathrm{H}), 6.70(\mathrm{~d}, J=9.2 \mathrm{~Hz}, 2 \mathrm{H}), 4.14(\mathrm{t}, J=4.0 \mathrm{~Hz}, 2 \mathrm{H})$, $3.92(\mathrm{t}, J=4.0 \mathrm{~Hz}, 2 \mathrm{H}), 3.64-3.68(\mathrm{~m}, 13 \mathrm{H}), 2.38(\mathrm{~s}, 3 \mathrm{H}) ;{ }^{13} \mathrm{C} \mathrm{NMR}$ (100 MHz, DMSO-d 6 , $\delta$ ppm): 158.73, 157.89, 157.24, 153.75, 152.99, 145.38, 135.07, 134.67, 134.21, 132.93, 130.60, 128.12, 121.30, 114.61, 102.10, 92.72, 70.47, 69.46, 68.53, 67.67, 60.61, 56.21, 55.61, 21.57; HRMS (ESI): calcd for $\mathrm{C}_{30} \mathrm{H}_{33} \mathrm{BrN}_{4} \mathrm{O}_{6} \mathrm{~S}([\mathrm{M}+$ $\left.\mathrm{H}]^{+}\right)$689.1202, found 689.1317 $\left([\mathrm{M}+\mathrm{H}]^{+}\right)$.

\section{Synthesis of precursor $18 \mathrm{e}$}

A similar reaction to that described above to prepare 18a was used to obtain 18e as a light yellow solid (0.57 g, 61\%). ${ }^{1} \mathrm{H}$ NMR $\left(\mathrm{DMSO}_{6}\right.$ ) $\delta: 9.25$ (s, br, 1H), 8.85 (s, br, 1H), $8.25(\mathrm{~s}, 1 \mathrm{H}), 7.90$ $(\mathrm{d}, J=8.4 \mathrm{~Hz}, 2 \mathrm{H}), 7.78(\mathrm{~d}, J=8.0 \mathrm{~Hz}, 2 \mathrm{H}), 7.66(\mathrm{~d}, J=8.8 \mathrm{~Hz}$, $2 \mathrm{H}), 7.42-7.47(\mathrm{~m}, 4 \mathrm{H}), 6.78(\mathrm{~d}, J=8.8 \mathrm{~Hz}, 2 \mathrm{H}), 4.14(\mathrm{t}, J=$ $4.0 \mathrm{~Hz}, 2 \mathrm{H}), 3.95(\mathrm{t}, J=4.0 \mathrm{~Hz}, 2 \mathrm{H}), 3.64(\mathrm{q}, J=4.4 \mathrm{~Hz}, 4 \mathrm{H}), 2.37$ $(\mathrm{s}, 3 \mathrm{H}) ;{ }^{13} \mathrm{C} \mathrm{NMR}\left(100 \mathrm{MHz}, \mathrm{CDCl}_{3}, \delta \mathrm{ppm}\right):$ 158.92, 157.60, 155.92, 155.15, 144.93, 141.38, 132.99, 132.40, 129.91, 128.08, 126.10, 125.63, 125.41, 125.16, 123.36, 122.87, 120.66, 114.93, 102.10, 93.91, 70.00, 69.35, 68.98, 67.81, 21.72; HRMS (ESI): calcd for $\mathrm{C}_{28} \mathrm{H}_{27} \mathrm{BrF}_{3} \mathrm{~N}_{4} \mathrm{O}_{5} \mathrm{~S}\left([\mathrm{M}+\mathrm{H}]^{+}\right)$667.0759, found 667.0865 $\left([\mathrm{M}+\mathrm{H}]^{+}\right)$.

\section{Synthesis of precursor $18 \mathrm{f}$}

A similar reaction to that described above to prepare 18a was used to obtain $18 f$ as a light yellow solid $(0.58 \mathrm{~g}, 66 \%) .{ }^{1} \mathrm{H}$ NMR $\left(\right.$ DMSO-d $\left._{6}\right) \delta: 9.27(\mathrm{~s}, \mathrm{br}, 1 \mathrm{H}), 8.81(\mathrm{~s}, \mathrm{br}, 1 \mathrm{H}), 8.26(\mathrm{~s}, 1 \mathrm{H}), 7.88-$ $7.90(\mathrm{~m}, 4 \mathrm{H}), 7.78(\mathrm{~d}, J=8.0 \mathrm{~Hz}, 2 \mathrm{H}), 7.41-7.49(\mathrm{~m}, 4 \mathrm{H}), 6.80(\mathrm{~d}, J$ $=9.2 \mathrm{~Hz}, 2 \mathrm{H}), 4.29(\mathrm{q}, J=7.2 \mathrm{~Hz}, 2 \mathrm{H}), 4.15(\mathrm{t}, J=4.0 \mathrm{~Hz}, 2 \mathrm{H})$, $3.96(\mathrm{t}, J=4.0 \mathrm{~Hz}, 2 \mathrm{H}), 3.64-3.67(\mathrm{~m}, 4 \mathrm{H}), 2.36(\mathrm{~s}, 3 \mathrm{H}), 1.31(\mathrm{t}, J$ $=7.2 \mathrm{~Hz}, 3 \mathrm{H}) ;{ }^{13} \mathrm{C} \mathrm{NMR}\left(100 \mathrm{MHz}, \mathrm{CDCl}_{3}, \delta \mathrm{ppm}\right): 166.22$, 158.89, 157.44, 155.80, 155.09, 144.91, 142.43, 133.00, 132.43, 130.65, 129.91, 128.07, 125.43, 122.80, 119.87, 114.96, 94.05, 70.00, 69.38, 68.99, 67.81, 60.95, 21.73, 14.49; HRMS (ESI): calcd for $\mathrm{C}_{30} \mathrm{H}_{32} \mathrm{BrN}_{4} \mathrm{O}_{7} \mathrm{~S}\left([\mathrm{M}+\mathrm{H}]^{+}\right)$671.1097, found 671.1213 $\left([\mathrm{M}+\mathrm{H}]^{+}\right)$.

\section{Synthesis of F-19 standard 8a}

To a stirred solution of compound $7(30 \mathrm{mg}, 0.05 \mathrm{mmol})$ in dry THF ( $4 \mathrm{~mL}$ ), tetrabutylammonium fluoride ( $0.5 \mathrm{~mL}, 1 \mathrm{M}$ in THF) was added. The mixture was heated using a digestion highpressure tank at $100{ }^{\circ} \mathrm{C}$ for $6-7 \mathrm{~h}$. After the intermediate 7 was completely consumed (as monitored by TLC, petroleum ether/ethyl acetate, $6 / 1, \mathrm{v} / \mathrm{v}$ ), the reaction was quenched with water, and then the mixture was extracted with ethyl acetate (3 $\times 10 \mathrm{~mL}$ ). The combined organic phase was dried over anhydrous sodium sulfate and concentrated under reduced pressure, which was further purified by silica gel column chromatography eluted with petroleum ether/ethyl acetate (10/ $1-4 / 1, \mathrm{v} / \mathrm{v})$ to give the pure compound $8 \mathrm{a}(1.4 \mathrm{mg})$ as a white solid. Yield: $6.3 \% ;{ }^{1} \mathrm{H} \mathrm{NMR}\left(\mathrm{CDCl}_{3}, 400 \mathrm{MHz}\right) \delta: 7.82(\mathrm{~s}, 1 \mathrm{H})$, $7.30(\mathrm{~d}, J=8.8 \mathrm{~Hz}, 4 \mathrm{H}), 6.83(\mathrm{~d}, J=8.6 \mathrm{~Hz}, 2 \mathrm{H}), 6.75(\mathrm{~d}, J=$ $8.5 \mathrm{~Hz}, 2 \mathrm{H}), 4.75(\mathrm{t}, J=4.1 \mathrm{~Hz}, 1 \mathrm{H}), 4.63(\mathrm{t}, J=3.9 \mathrm{~Hz}, 1 \mathrm{H}), 4.16$ $(\mathrm{t}, J=3.9 \mathrm{~Hz}, 1 \mathrm{H}), 4.10(\mathrm{t}, J=4.0 \mathrm{~Hz}, 1 \mathrm{H}), 3.78(\mathrm{~s}, 3 \mathrm{H}) ;{ }^{13} \mathrm{C} \mathrm{NMR}$ (100 MHz, DMSO-d $\left.{ }_{6}\right) \delta: 158.74,157.93,157.24,153.51,152.99$, $135.07,134.67,134.47,122.67,121.33$, 116.71, 114.74, 92.78, 83.58, 81.91, 67.87, 67.68, 55.61; HRMS (ESI): calcd for $\mathrm{C}_{19^{-}}$ $\mathrm{H}_{19} \mathrm{BrFN}_{4} \mathrm{O}_{2}\left([\mathrm{M}+\mathrm{H}]^{+}\right)$433.0597, found $433.0621\left([\mathrm{M}+\mathrm{H}]^{+}\right)$.

\section{Synthesis of F-19 standard 8b}

A similar reaction to that described above to prepare 7 was used to obtain $8 \mathrm{~b}(0.46 \mathrm{~g}, 68 \%)$ as a white solid; ${ }^{1} \mathrm{H}$ NMR $(400 \mathrm{MHz}$, DMSO- $\left.d_{6}\right) \delta: 9.18(\mathrm{~s}, 1 \mathrm{H}), 8.47(\mathrm{~s}, 1 \mathrm{H}), 8.16(\mathrm{~s}, 1 \mathrm{H}), 7.50(\mathrm{~d}, 2 \mathrm{H})$, $6.91(\mathrm{~s}, 2 \mathrm{H}), 6.75(\mathrm{~d}, 2 \mathrm{H}), 4.79-4.75(\mathrm{~m}, 1 \mathrm{H}), 4.67-4.63(\mathrm{~m}, 1 \mathrm{H})$, 4.17 (s, 1H), 4.12-4.07 (m, 1H), 3.69-3.65 (m, 10H); ${ }^{13} \mathrm{C}$ NMR $\left(100 \mathrm{MHz}, \mathrm{DMSO}-d_{6}\right) \delta: 158.74,157.93,157.24,153.51,152.99$, $135.07,134.67,134.47,121.33,114.74,102.11$, 92.78, 83.58, 81.91, 67.87, 67.68, 60.61, 56.21, 55.61; HRMS (ESI): calcd for $\mathrm{C}_{21} \mathrm{H}_{23} \mathrm{BrFN}_{4} \mathrm{O}_{4}\left([\mathrm{M}+\mathrm{H}]^{+}\right)$493.0808, found $493.0887\left([\mathrm{M}+\mathrm{H}]^{+}\right)$.

\section{Synthesis of F-19 standard 8c}

A similar reaction to that described above to prepare 7 was used to obtain 8c (0.69 g, 90\%) as a white solid; ${ }^{1} \mathrm{H}$ NMR $(400 \mathrm{MHz}$, DMSO- $\left.d_{6}\right) \delta: 9.26(\mathrm{~s}, 1 \mathrm{H}), 8.85(\mathrm{~s}, 1 \mathrm{H}), 8.25(\mathrm{~s}, 1 \mathrm{H}), 7.89(\mathrm{~d}, 2 \mathrm{H})$, 7.66 (d, 2H), 7.47 (d, 2H), 6.83 (d, 2H), 4.80-4.75 (m, 1H), 4.70$4.63(\mathrm{~m}, 1 \mathrm{H}), 4.23-4.17$ (m, 1H), 4.15-4.11 (m, $1 \mathrm{H}) ;{ }^{13} \mathrm{C}$ NMR $\left(100 \mathrm{MHz}, \mathrm{DMSO}-d_{6}\right) \delta: 158.81,156.82,153.84,143.26,134.14$, 125.82 , 124.11, 123.84, 123.10, 121.96, 114.80, 83.27, 82.17, 
67.78, 67.66; HRMS (ESI): calcd for $\mathrm{C}_{19} \mathrm{H}_{16} \mathrm{BrFN}_{4} \mathrm{O}_{4}\left([\mathrm{M}+\mathrm{H}]^{+}\right)$ 471.0365, found $471.0440\left([\mathrm{M}+\mathrm{H}]^{+}\right)$.

\section{Synthesis of F-19 standard 8d}

A similar reaction to that described above to prepare 7 was used to obtain 8d (0.94 g, 78\%) as a white solid; ${ }^{1} \mathrm{H}$ NMR $(400 \mathrm{MHz}$, DMSO- $\left.d_{6}\right) \delta$ : $9.26(\mathrm{~s}, 1 \mathrm{H}), 8.80(\mathrm{~s}, 1 \mathrm{H}), 8.26(\mathrm{~s}, 1 \mathrm{H}), 7.94-7.80(\mathrm{~m}$, $4 \mathrm{H}), 7.49(\mathrm{~d}, 2 \mathrm{H}), 6.85(\mathrm{~d}, 2 \mathrm{H}), 4.82-4.76(\mathrm{~m}, 1 \mathrm{H}), 4.70-4.63(\mathrm{~m}$, $1 \mathrm{H}), 4.30(\mathrm{q}, 2 \mathrm{H}), 4.24-4.19(\mathrm{~m}, 1 \mathrm{H}), 4.17-4.12(\mathrm{~m}, 1 \mathrm{H}), 1.32(\mathrm{t}$, $3 \mathrm{H}) ;{ }^{13} \mathrm{C}$ NMR $\left(100 \mathrm{MHz}, \mathrm{CDCl}_{3}\right) \delta: 166.23,158.81,157.33$, $155.83,154.92,142.35,132.59,130.67,125.55,122.90,119.92$, 115.08, 94.15, 82.66, 81.52, 67.69, 67.55, 60.97, 14.47; HRMS (ESI): calcd for $\mathrm{C}_{21} \mathrm{H}_{21} \mathrm{BrFN}_{4} \mathrm{O}_{3}\left([\mathrm{M}+\mathrm{H}]^{+}\right)$475.0703, found 475.0784 $\left([\mathrm{M}+\mathrm{H}]^{+}\right)$.

\section{Synthesis of F-19 standard 8e}

A similar reaction to that described above to prepare 7 was used to obtain $8 \mathrm{e}(1.20 \mathrm{~g}, 82 \%)$ as a white solid; ${ }^{1} \mathrm{H}$ NMR $(400 \mathrm{MHz}$, DMSO- $\left.d_{6}\right) \delta$ : $9.16(\mathrm{~s}, 1 \mathrm{H}), 8.46(\mathrm{~s}, 1 \mathrm{H}), 8.16(\mathrm{~s}, 1 \mathrm{H}), 7.60-7.40(\mathrm{~m}$, $3 \mathrm{H}), 6.91(\mathrm{~s}, 3 \mathrm{H}), 6.77-6.69(\mathrm{~m}, 3 \mathrm{H}), 4.68-4.55(\mathrm{~m}, 1 \mathrm{H}), 4.52-4.44$ $(\mathrm{m}, 1 \mathrm{H}), 4.04-3.95(\mathrm{~m}, 3 \mathrm{H}), 3.79-3.72(\mathrm{~m}, 4 \mathrm{H}), 3.69-3.64(\mathrm{~m}$, $13 \mathrm{H}) ;{ }^{13} \mathrm{C}$ NMR $\left(100 \mathrm{MHz}, \mathrm{DMSO}-d_{6}\right) \delta: 158.76,157.93,157.23$, 153.80, 152.99, 135.07, 134.67, 134.21, 121.32, 114.63, 102.10, $92.70,84.39,82.74,70.41,70.22,69.58,67.78,60.61,56.21$, 55.60; HRMS (ESI): calcd for $\mathrm{C}_{23} \mathrm{H}_{27} \mathrm{BrFN}_{4} \mathrm{O}_{5}\left([\mathrm{M}+\mathrm{H}]^{+}\right)$ 537.1071, found $537.1141\left([\mathrm{M}+\mathrm{H}]^{+}\right)$.

\section{Synthesis of F-19 standard 8f}

A similar reaction to that described above to prepare 7 was used to obtain $8 f(1.08 \mathrm{~g}, 75 \%)$ as a white solid; ${ }^{1} \mathrm{H}$ NMR $(400 \mathrm{MHz}$, DMSO- $\left.d_{6}\right) \delta: 9.25(\mathrm{~s}, 1 \mathrm{H}), 8.85(\mathrm{~s}, 1 \mathrm{H}), 8.25(\mathrm{~s}, 1 \mathrm{H}), 7.97-7.78(\mathrm{~m}$, $2 \mathrm{H}), 7.70-7.62(\mathrm{~m}, 2 \mathrm{H}), 7.50-7.41(\mathrm{~m}, 2 \mathrm{H}), 6.86-6.76(\mathrm{~m}, 2 \mathrm{H})$, 4.65-4.56 (m, 1H), 4.52-4.45 (m, 1H), 4.10-3.99 (m, 2H), 3.82$3.72(\mathrm{~m}, 3 \mathrm{H}), 3.72-3.64(\mathrm{~m}, 1 \mathrm{H}) ;{ }^{13} \mathrm{C} \mathrm{NMR}\left(100 \mathrm{MHz}, \mathrm{CDCl}_{3}\right) \delta$ : 158.84, 157.43, 155.94, 155.32, 141.33, 132.21, 126.16, 122.93, 120.66, 115.02, 83.85, 82.73, 70.76, 70.63, 70.06, 67.93; HRMS (ESI): calcd for $\mathrm{C}_{21} \mathrm{H}_{20} \mathrm{BrF}_{4} \mathrm{~N}_{4} \mathrm{O}_{2}\left([\mathrm{M}+\mathrm{H}]^{+}\right)$515.0628, found $515.0704\left([\mathrm{M}+\mathrm{H}]^{+}\right)$.

\section{Synthesis of F-19 standard $8 \mathrm{~g}$}

A similar reaction to that described above to prepare 7 was used to obtain $8 \mathrm{~g}(1.28 \mathrm{~g}, 88 \%)$ as a white solid; ${ }^{1} \mathrm{H}$ NMR $(400 \mathrm{MHz}$, DMSO- $\left.d_{6}\right) \delta: 9.25(\mathrm{~s}, 1 \mathrm{H}), 8.80(\mathrm{~s}, 1 \mathrm{H}), 8.25(\mathrm{~s}, 1 \mathrm{H}), 7.88(\mathrm{~s}, 5 \mathrm{H})$, 7.65-7.36 (m, 2H), 6.95-6.73 (m, 2H), 4.68-4.55 (m, 1H), 4.55$4.43(\mathrm{~m}, 1 \mathrm{H}), 4.37-4.23(\mathrm{~m}, 3 \mathrm{H}), 4.10-4.01(\mathrm{~m}, 3 \mathrm{H}), 3.82-3.72$ (m, 4H), 3.70-3.63 (m, 1H), 1.35-1.30 (m, 4H); ${ }^{13} \mathrm{C}$ NMR (100 $\left.\mathrm{MHz} \mathrm{CDCl}_{3}\right) \delta: 166.24,158.98,157.54,155.77,155.18,142.45$, $132.42,130.65,125.40,122.84,119.82,115.00,93.98,83.86$, 82.74, 70.76, 70.63, 70.07, 67.91, 60.95, 14.49; HRMS (ESI): calcd for $\mathrm{C}_{23} \mathrm{H}_{25} \mathrm{BrFN}_{4} \mathrm{O}_{4}\left([\mathrm{M}+\mathrm{H}]^{+}\right) 519.0965$, found 519.1032 $\left([\mathrm{M}+\mathrm{H}]^{+}\right)$.

\section{Synthesis of F-19 standard $8 \mathrm{~h}$}

A mixture of compound $8 \mathrm{~d}(0.50 \mathrm{~g}, 1.1 \mathrm{mmol})$ and potassium hydroxide $(2.00 \mathrm{~g}, 35.7 \mathrm{mmol})$ in $\mathrm{EtOH} / \mathrm{H}_{2} \mathrm{O}(20 \mathrm{~mL}, 1 / 1, \mathrm{v} / \mathrm{v})$ was stirred at $90{ }^{\circ} \mathrm{C}$. When the compound 8d was completely consumed (as monitored by TLC, petroleum ether/ethyl acetate, $6 / 1, v / v)$, the mixed solution was concentrated under reduced pressure. The $\mathrm{pH}$ of the resulting residue was adjusted to 1-2 by $1 \mathrm{M} \mathrm{HCl}$ (aq.), and then filtrated and washed with water to get the pure compound $8 \mathbf{h}(0.30)$ as a white solid. Yield: $63 \% ;{ }^{1} \mathrm{H}$ NMR $\left(400 \mathrm{MHz}\right.$, DMSO- $\left.d_{6}\right) \delta: 9.26(\mathrm{~s}, 1 \mathrm{H}), 8.75(\mathrm{~s}, 1 \mathrm{H}), 8.25(\mathrm{~s}$, $1 \mathrm{H}), 7.95-7.78(\mathrm{~m}, 4 \mathrm{H}), 7.49(\mathrm{~d}, 2 \mathrm{H}), 6.84(\mathrm{~d}, 2 \mathrm{H}), 4.82-4.76(\mathrm{~m}$, $1 \mathrm{H}), 4.70-4.64(\mathrm{~m}, 1 \mathrm{H}), 4.24-4.19(\mathrm{~m}, 1 \mathrm{H}), 4.17-4.11(\mathrm{~m}$, $1 \mathrm{H}) \mathrm{ppm} ;{ }^{13} \mathrm{C}$ NMR $\left(100 \mathrm{MHz}, \mathrm{DMSO}-d_{6}\right) \delta: 167.83,165.99$, $158.81,158.56,156.67,153.80,144.08,143.59$, 134.14, 130.25, 126.08, 124.63, 121.97, 114.81, 93.35, 83.57, 81.92, 67.84, 67.65, 60.96; HRMS (ESI): calcd for $\mathrm{C}_{19} \mathrm{H}_{16} \mathrm{BrFN}_{4} \mathrm{O}_{3}\left([\mathrm{M}+\mathrm{H}]^{+}\right)$ 447.0390, found $447.0461\left([\mathrm{M}+\mathrm{H}]^{+}\right)$.

\section{Synthesis of F-19 standard 8i}

Compound $8 \mathbf{i}(0.37 \mathrm{~g})$ was obtained as a white solid according to the general procedure described for $\mathbf{8 h}$ starting from the pyrimidine derivative $8 \mathrm{~g}(0.50 \mathrm{~g}, 0.96 \mathrm{mmol})$ and potassium hydroxide (2.00 g, $35.7 \mathrm{mmol})$. Yield: $78 \%$; ${ }^{1} \mathrm{H}$ NMR $(400 \mathrm{MHz}$, DMSO- $\left.d_{6}\right) \delta: 12.72(\mathrm{~s}, 1 \mathrm{H}), 9.25(\mathrm{~s}, 1 \mathrm{H}), 8.75(\mathrm{~s}, 1 \mathrm{H}), 8.25(\mathrm{~s}, 1 \mathrm{H})$, 7.91-7.80 (m, 4H), 7.54-7.42 (m, 2H), 6.88-6.78 (m, 2H), 4.64$4.58(\mathrm{~m}, 1 \mathrm{H}), 4.52-4.46(\mathrm{~m}, 1 \mathrm{H}), 4.06(\mathrm{t}, 2 \mathrm{H}), 3.80-3.73(\mathrm{~m}, 3 \mathrm{H})$, 3.71-3.66 (m, 1H) ppm; ${ }^{13} \mathrm{C} \mathrm{NMR}\left(100 \mathrm{MHz}, \mathrm{DMSO}-d_{6}\right) \delta: 167.61$, 165.96, 158.83, 158.59, 156.65, 154.13, 143.76, 133.85, 130.28, 130.06, 125.62, 124.63, 122.03, 114.73, 93.28, 84.40, 82.75, 70.40, 70.22, 69.57, 67.75, 60.95; HRMS (ESI): calcd for $\mathrm{C}_{19^{-}}$ $\mathrm{H}_{16} \mathrm{BrFN}_{4} \mathrm{O}_{3}\left([\mathrm{M}+\mathrm{H}]^{+}\right)$491.0652, found $491.0718\left([\mathrm{M}+\mathrm{H}]^{+}\right)$.

\section{FAK inhibitory assay}

The inhibition tests of the title compounds $\mathbf{8 a - 8 i}$ against FAK were performed using the HTRF® (Homogeneous TimeResolved Fluorescence Methodologies) kinEASETM TK kit. The concentration of the enzyme used in the assay, as well as the enzymatic reaction time and the ATP concentration were optimized before the compound testing. Here, $0.11 \mathrm{ng} \mu \mathrm{L}^{-1}$ enzyme was chosen to be used with $13.8 \mu \mathrm{M}$ ATP to react for $50 \mathrm{~min}$ at room temperature.

During the enzymatic reaction step, $4 \mu \mathrm{L}$ of the compound and $2 \mu \mathrm{L}$ TK substrate-biotin were incubated with $2 \mu \mathrm{L}$ kinase. 2 $\mu \mathrm{L}$ ATP was added to start the enzymatic reaction. Then, the enzymatic buffer from the HTRF® kinEASE ${ }^{\mathrm{TM}}$ TK kit was added, following by the addition of $5 \mathrm{mM} \mathrm{MgCl}_{2}, 1 \mathrm{mM}$ DTT, and $25 \mathrm{nM}$ SEB.

The detection reagents $\left(5 \mu \mathrm{L} \quad \mathrm{Eu}^{3+}\right.$-cryptate labeled TKantibody and $5 \mu \mathrm{L}$ Steptavidin-XL665) dissolved in the detection buffer (in the presence of EDTA) were mixed and added to the reaction system. The TR-FRET signal was proportional to the phosphorylation level and was detected by a plate reader (BMG FS) after incubation for $1 \mathrm{~h}$. For each compound, the $\mathrm{IC}_{50}$ value was determined from a sigmoid dose-response curve using GraphPad Prism (GraphPad Software, San Diego, CA, USA).

\section{Partition coefficient determination}

The determination of the partition coefficients of the radiotracers $\left[{ }^{18} \mathrm{~F}\right]-\mathbf{8 a},\left[{ }^{18} \mathrm{~F}\right]-\mathbf{8 c},\left[{ }^{18} \mathrm{~F}\right]-\mathbf{8 h}$ and $\left[{ }^{18} \mathrm{~F}\right]-\mathbf{8 i}$ was carried out 
according to the following procedure: first, the same volume of $n$-octanol and PBS (phosphate buffer saline, $0.05 \mathrm{M}$, pH 7.4) was mixed, and each phase was presaturated with the opposite phase overnight before use. Then, to a centrifuge tube was added a solution of ${ }^{18} \mathrm{~F}$-labeled tracer $(370 \mathrm{kBq}, 10 \mu \mathrm{Ci})$ in 0.1 $\mathrm{mL}$ normal saline, $0.9 \mathrm{~mL}$ PBS (presaturated with the opposite phase overnight), and $1.0 \mathrm{~mL} n$-octanol (presaturated with the opposite phase overnight) in sequence. The centrifuge tube was vortexed for $0.5-1.0 \mathrm{~min}$ at room temperature, followed by centrifugation for $5 \mathrm{~min}$ at $5000 \mathrm{rpm}$. After standing for a while, two samples were transferred from the $n$-octanol $(100 \mu \mathrm{L})$ and PBS $(100 \mu \mathrm{L})$ layers to the counting tubes and were measured in a gamma counter. The partition coefficient was expressed as the logarithm of the ratio of the radioactivity from the $n$-octanol phase versus the PBS phase. The measurement was done in triplicate and repeated three times.

\section{In vitro stability studies}

$\left[{ }^{18} \mathrm{~F}\right]-\mathbf{8 a},\left[{ }^{18} \mathrm{~F}\right]-\mathbf{8 c},\left[{ }^{18} \mathrm{~F}\right]-\mathbf{8 h}$, and $\left[{ }^{18} \mathrm{~F}\right]-\mathbf{8 i}(370 \mathrm{kBq}, 10 \mu \mathrm{Ci})$ after HPLC purification were dissolved in $100 \mu \mathrm{L}$ of normal saline, and then mixed with $500 \mu \mathrm{L}$ of normal saline at $37^{\circ} \mathrm{C}$ for $1 \mathrm{~h}$ and $2 \mathrm{~h}$, respectively. About $100 \mu \mathrm{L}$ of the solution was analyzed by radio-HPLC.

The in vitro stability of the ${ }^{18} \mathrm{~F}$-labeled tracers in mouse plasma was determined using the following procedure: (1) first, incubate $370 \mathrm{kBq}$ of the HPLC-purified radiotracers in $100 \mu \mathrm{L}$ of normal saline with $500 \mu \mathrm{L}$ of murine plasma at $37^{\circ} \mathrm{C}$ for $1 \mathrm{~h}$ and $2 \mathrm{~h}$, respectively; (2) after centrifuging the plasma proteins at $5000 \mathrm{rpm}$ for $5 \mathrm{~min}$ at $4{ }^{\circ} \mathrm{C}$, they were precipitated by adding 200 $\mu \mathrm{L}$ of acetonitrile. The supernatant was collected. Approximately $100 \mu \mathrm{L}$ of the supernatant solution was loaded for the HPLC analysis.

\section{In vivo biodistribution studies in $\mathbf{S 1 8 0}$-bearing mice}

An S180 ascites sarcoma mouse was sacrificed and the ascites was immediately drawn off from the carcass and made into an S180 sarcoma cell suspension (diluted four times by normal saline). Then, the normal ICR mice were inoculated subcutaneously into the right front flank with the diluted ascites sarcoma cell suspension $(100 \mu \mathrm{L}$ per mouse, containing about $5 \times 10^{6}$ tumor cells by cell count).

The in vivo biodistribution studies could be conducted until the tumors reached a size of $0.5-0.8 \mathrm{~cm}$ in diameter (i.e., for about one week). A normal saline solution containing the ${ }^{18} \mathrm{~F}$ labeled tracers $\left[{ }^{18} \mathrm{~F}\right]-8 \mathbf{8 a},\left[{ }^{18} \mathrm{~F}\right]-8 \mathrm{c},\left[{ }^{18} \mathrm{~F}\right]-8 \mathrm{~h}$, and $\left[{ }^{18} \mathrm{~F}\right]-8 \mathrm{i}(370 \mathrm{kBq}$ per $100 \mu \mathrm{L}$ ) was injected via the tail vein for each of the S180tumor-bearing mice. The mice ( $n=5$ for each time point) were sacrificed at 5, 15, 30, 60, and $120 \mathrm{~min}$ post-injection. The tissues and organs of interest were anatomized and weighed, and the radioactivity was determined with an automatic $\gamma$-counter. The percent dose per gram of wet tissue was calculated by a comparison of the tissue counts to suitably diluted aliquots of the injected material. The values were expressed as the mean $\pm \mathrm{SD}(n=5)$.

\section{MicroPET imaging}

The S180-tumor-bearing mice were injected intravenously with approximately $3.7 \mathrm{MBq}$ of $\left[{ }^{18} \mathrm{~F}\right]-8 \mathrm{a}$ in $300 \mu \mathrm{L}$ normal saline, anesthetized with $1.5 \%$ isoflurane in air (about $1.5 \mathrm{~mL} \mathrm{~min}^{-1}$ ), and fixed near the center of the microPET scanner (SuperArgus microPET/CT). Static scans (for $30 \mathrm{~min}$ and $60 \mathrm{~min}, 10 \mathrm{~min}$ scans for each time point) were obtained on a SuperArgus microPET/CT. Then, the images were reconstructed with the SEDECAL reconstruction software and the images were exported by MMWKS SUPERARGUS software.

\section{Results and discussion}

\section{Chemistry}

The synthetic route used to prepare the pyrimidine derivative $\mathbf{8 a}$ is shown in Scheme 1. The starting material 4-nitrophenol 1 was treated with ethane-1,2-diyl bis(4-methylbenzenesulfonate) to give compound 2 , which was reduced by $\mathrm{Zn}$ to obtain compound 3. Intermediate $6 \mathbf{a}$ was obtained by the reaction of 5bromo-2,4-dichloropyrimidine 4 and 4-methoxyaniline 5a in i$\mathrm{PrOH}$ using $\mathrm{K}_{2} \mathrm{CO}_{3}$ as a base at room temperature with a yield of $78 \%$. Compound 7 could be prepared by compounds 3 and $\mathbf{6 a}$ in 1,4-dioxane at $100{ }^{\circ} \mathrm{C}$ using $p$-toluene sulfonic acid as the catalyst, which was further refluxed in THF in the presence of TBAF to provide the target compound $\mathbf{8 a}$.

The synthetic route used to prepare the pyrimidine derivatives $\mathbf{8 b}-\mathbf{g}$ is shown in Scheme 2. The fluorinated products 10ab were obtained starting from the commercially available materials $\mathbf{9 a - b}$, followed by etherification and hydrogenation to give the key intermediates $\mathbf{1 2 a - b}$ in excellent yields. Another

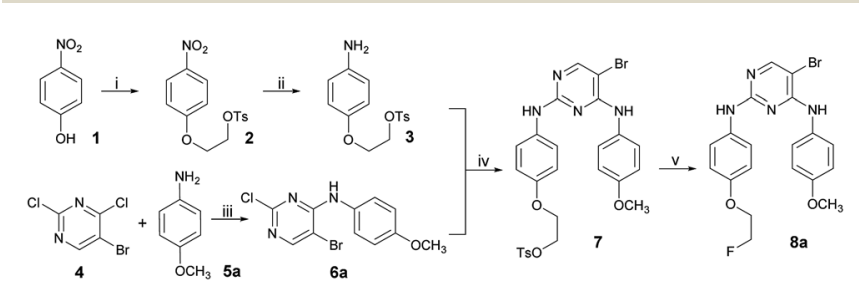

Scheme 1 Reagents and conditions: (i) ethane-1,2-diyl bis(4-methylbenzenesulfonate), $\mathrm{K}_{2} \mathrm{CO}_{3}, 18-$ crown-6, $56^{\circ} \mathrm{C}$; (ii) $\mathrm{Zn}$, acetic acid, room temperature, $12 \mathrm{~h}$; (iii) i- $\mathrm{PrOH}, \mathrm{K}_{2} \mathrm{CO}_{3}$, rt; (iv) $\mathrm{TsOH} \cdot \mathrm{H}_{2} \mathrm{O}, 1,4-$ dioxane, $100^{\circ} \mathrm{C}$; (v) TBAF, THF, reflux, 6-7 h.

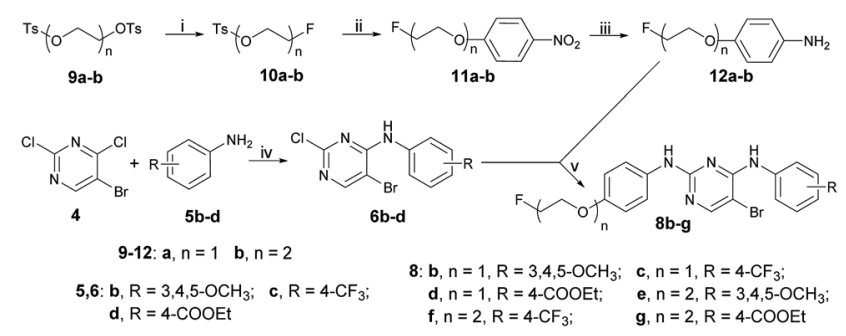

Scheme 2 Reagents and conditions: (i) TBAF, THF, $\mathrm{N}_{2}, 80^{\circ} \mathrm{C}, 20 \mathrm{~h}$; (ii) p-nitrophenol, $\mathrm{K}_{2} \mathrm{CO}_{3}, \mathrm{DMF}, \mathrm{N}_{2}, 80{ }^{\circ} \mathrm{C}, 2 \mathrm{O}$; (iii) $\mathrm{CH}_{3} \mathrm{OH}-\mathrm{THF}, 7.5 \%$ $\mathrm{Pd}-\mathrm{C}, \mathrm{H}_{2}, \mathrm{rt}, 4 \mathrm{~h}$; (iv) i-PrOH, $\mathrm{K}_{2} \mathrm{CO}_{3} \mathrm{rt}$; (v) $\mathrm{TsOH} \cdot \mathrm{H}_{2} \mathrm{O}, 1,4$-dioxane, $100{ }^{\circ} \mathrm{C}, 3 \mathrm{~h}$. 
important kind of intermediate $\mathbf{6 b}-\mathbf{d}$ could be easily prepared by compounds $\mathbf{4}$ and $\mathbf{5 b} \mathbf{b}-\mathbf{d}$, whereby the former further reacted with compounds $\mathbf{1 2 a}-\mathbf{b}$ in 1,4 -dioxane at $100{ }^{\circ} \mathrm{C}$ to provide the target pyrimidine derivatives $\mathbf{8 b} \mathbf{b} \mathbf{g}$ using $p$-toluene sulfonic acid as the catalyst with $68-90 \%$ yields.

The synthetic route used to prepare the pyrimidine derivatives $\mathbf{8 h}$ and $\mathbf{8 i}$ is shown in Scheme 3. The target compounds $\mathbf{8 h}$ and $\mathbf{8} \mathbf{i}$ with moderate yields were easily synthesized by pyrimidine derivatives $\mathbf{8 d}$ and $\mathbf{8 g}$ in the mixed solution of ethanol and water at $90{ }^{\circ} \mathrm{C}$ in the presence of $\mathrm{KOH}$.

All the newly synthesized target pyrimidine derivatives were characterized by ${ }^{1} \mathrm{H}$ NMR, ${ }^{13} \mathrm{C}$ NMR, and MS spectra. The spectral data were in accordance with the assigned structures, and all the spectral data are listed in the Experimental section.

\section{FAK inhibitory assay}

The prepared compounds $\mathbf{8 a}-\mathbf{i}$ were evaluated for their in vitro inhibitory activities against FAK using 16-OTS-1 as the positive control. The obtained results are shown in Table 1.

The results in Table 1 demonstrated that all the target compounds showed superior inhibition against FAK compared to the reference 18c. The most active compound $\mathbf{8 i}$ displayed an $\mathrm{IC}_{50}$ value of $0.060 \mu \mathrm{M}$ against FAK, which was more than 500fold lower than $18 \mathrm{c}\left(\mathrm{IC}_{50}=33.290 \mu \mathrm{M}\right)$. When $n=1$, compound $\mathbf{8 h}$ with a carboxyl group exhibited strong inhibitory activity with an $\mathrm{IC}_{50}$ value of $0.285 \mu \mathrm{M}$, while when $n=2$, the carboxylgroup-modified derivative $\mathbf{8 i}$ was still the most active one. These outcomes suggested that the carboxyl group was favorable to exert FAK inhibition for this type of pyrimidine derivatives. However, with the change of the carboxyl group into a carboxylic

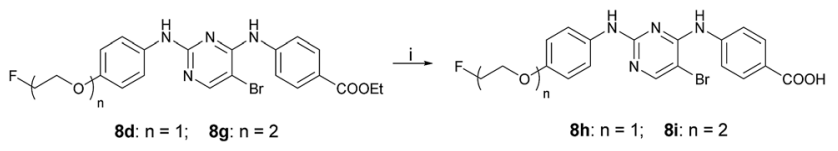

Scheme 3 Reagents and conditions: (i) (a) $\mathrm{KOH}, \mathrm{EtOH}-\mathrm{H}_{2} \mathrm{O}(1: 1)$, $90^{\circ} \mathrm{C}$; (b) $1 \mathrm{M} \mathrm{HCl}$.

Table 1 SAR-table of target pyrimidine derivatives

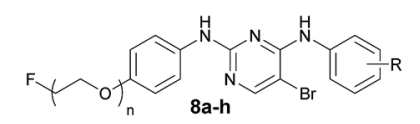

\begin{tabular}{lllr}
\hline Compds & $n$ & $\mathrm{R}$ & \multicolumn{1}{c}{$\mathrm{IC}_{50} / \mu \mathrm{M}$} \\
\hline $\mathbf{8 a}$ & 1 & $4-\mathrm{OCH}_{3}$ & 1.085 \\
$\mathbf{8 b}$ & 1 & $3,4,5-\mathrm{OCH}_{3}$ & 1.730 \\
$\mathbf{8 c}$ & 1 & $4-\mathrm{CF}_{3}$ & 3.258 \\
$\mathbf{8 d}$ & 1 & $4-\mathrm{COOEt}$ & 9.423 \\
$\mathbf{8 e}$ & 2 & $3,4,5-\mathrm{OCH}$ & 0.768 \\
$\mathbf{8 f}$ & 2 & $4-\mathrm{CF}_{3}$ & 0.722 \\
$\mathbf{8 g}$ & 2 & $4-\mathrm{COOEt}$ & 4.419 \\
$\mathbf{8 h}$ & 1 & $4-\mathrm{COOH}$ & 0.285 \\
$\mathbf{8 i}$ & 2 & $4-\mathrm{COOH}$ & 0.060 \\
$\mathbf{1 8 c}$ & & & 33.290
\end{tabular}

ester moiety, the inhibitory activity is reduced a lot. Comparing compounds with $n=1(\mathbf{8 a}-\mathbf{d}, \mathbf{8 h})$ to $n=2(\mathbf{8 e}-\mathbf{g}, \mathbf{8 i})$, the pyrimidine derivatives $\mathbf{8 e}-\mathbf{g}$ and $\mathbf{8 i}$ generally showed stronger activity, which indicated that the length of the aliphatic chain has an important effect on the FAK inhibitory activity.

\section{Radiolabeling}

Encouraged by the good inhibitory activity and docking results of most of the newly prepared pyrimidine derivatives against FAK, a radiofluorination method for the preparation of $\left[{ }^{18} \mathrm{~F}\right]-8$ was developed with different reactions.

Scheme 4 describes the synthesis of compound $\left[{ }^{18} \mathrm{~F}\right]-\mathbf{8 a}$, which could be easily obtained with the yield of $20 \%$ by the reaction of the tosylate precursor 7 with $\left[{ }^{18} \mathrm{~F}\right]$ fluoride/potassium carbonate and Kryptofix 2.2.2. in anhydrous acetonitrile using a digestion high-pressure tank at $100{ }^{\circ} \mathrm{C}$ for $15 \mathrm{~min}$.

The synthetic route for the preparation of the radioactive derivatives $\left[{ }^{18} \mathrm{~F}\right]-\mathbf{8 c},\left[{ }^{18} \mathrm{~F}\right]-\mathbf{8 d},\left[{ }^{18} \mathrm{~F}\right]-\mathbf{8 g},\left[{ }^{18} \mathrm{~F}\right]-\mathbf{8 h}$, and $\left[{ }^{18} \mathrm{~F}\right]-\mathbf{8 i}$ is outlined in Scheme 5. The starting materials 13a-b were followed by sulfonylation, etherification, and hydrogenation to give the intermediates $\mathbf{1 6 a}-\mathbf{b}$, which further reacted with $\mathbf{6 c}$ and 6d to provide the pyrimidine derivatives $17 \mathbf{a}-\mathbf{c}$. Then the sulfonylated products $18 \mathrm{a}-\mathrm{c}$ were treated with $\left[{ }^{18} \mathrm{~F}\right]$ fluoride/ potassium carbonate and Kryptofix 2.2.2. in anhydrous acetonitrile using a digestion high-pressure tank at $160{ }^{\circ} \mathrm{C}$ for $15 \mathrm{~min}$ to give the radioactive derivatives $\left[{ }^{18} \mathrm{~F}\right]-8 \mathrm{c}(16 \%),\left[{ }^{18} \mathrm{~F}\right]-8 d$, and

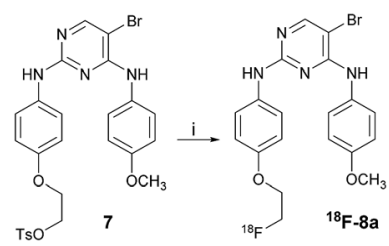

Scheme 4 Reagents and conditions: (i) anhydrous KF, Kryptofix 2.2.2., anhydrous acetonitrile, $100{ }^{\circ} \mathrm{C}, 15 \mathrm{~min}$.

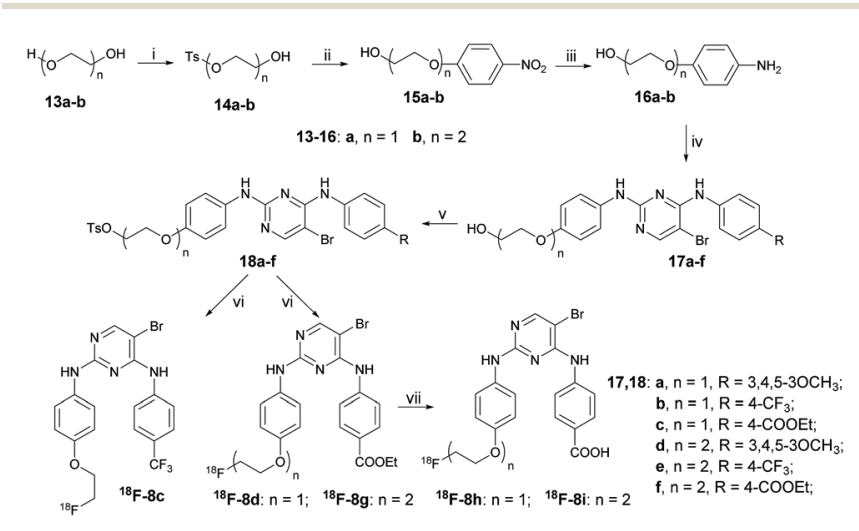

Scheme 5 Reagents and conditions: (i) TsCl, TEA, DCM, 0-5 ${ }^{\circ} \mathrm{C}, 3 \mathrm{~h}$; (ii) $p$-nitrophenol, $\mathrm{K}_{2} \mathrm{CO}_{3}, \mathrm{DMF}, 75^{\circ} \mathrm{C}$; (iii) $\mathrm{EtOH}, 7.5 \% \mathrm{Pd}-\mathrm{C}, \mathrm{H}_{2}, \mathrm{rt}, 4 \mathrm{~h}$; (iv) $6 \mathrm{c}, 6 \mathrm{~d}, \mathrm{TsOHS} \cdot \mathrm{H}_{2} \mathrm{O}, 1,4$-dioxane, $100{ }^{\circ} \mathrm{C}, 5 \mathrm{~h}$; (v) TsCl, TEA, DMAP, DCM, room temperature, $3 \mathrm{~h}$; (vi) anhydrous KF, Kryptofix 2.2.2., anhydrous acetonitrile, $160{ }^{\circ} \mathrm{C}, 15 \mathrm{~min}$; (vii) $1 \mathrm{M} \mathrm{NaOH}, \mathrm{EtOH}, 85^{\circ} \mathrm{C}$, $10 \mathrm{~min}$. 
$\left[{ }^{18} \mathrm{~F}\right]-\mathbf{8 g}$. Compounds $\left[{ }^{18} \mathrm{~F}\right]-\mathbf{8 h}(7 \%)$ and $\left[{ }^{18} \mathrm{~F}\right]-\mathbf{8 i}(9 \%)$ were obtained by further treating $\left[{ }^{18} \mathrm{~F}\right]-\mathbf{8 d}$ and $\left[{ }^{18} \mathrm{~F}\right]-8 \mathrm{~g}$ with $1 \mathrm{M} \mathrm{NaOH}$ in EtOH at $85{ }^{\circ} \mathrm{C}$ for $10 \mathrm{~min}$.

The radiochemical purity of the radiotracers $\left[{ }^{18} \mathrm{~F}\right]-\mathbf{8 a},\left[{ }^{18} \mathrm{~F}\right]-$ $\mathbf{8 c},\left[{ }^{18} \mathrm{~F}\right]-\mathbf{8 h}$, and $\left[{ }^{18} \mathrm{~F}\right]-\mathbf{8 i}$ was greater than $98 \%$ after purification by high performance liquid chromatography (HPLC). The identity of the ${ }^{18} \mathrm{~F}$-labeled tracers was verified by a comparison of their retention times with those of the corresponding nonradioactive F-19 standards $\mathbf{8 a}, \mathbf{8 c}, \mathbf{8 h}$, and $\mathbf{8 i}$ via co-injection. The retention times of $\left[{ }^{18} \mathrm{~F}\right]-\mathbf{8 a},\left[{ }^{18} \mathrm{~F}\right]-\mathbf{8 c},\left[{ }^{18} \mathrm{~F}\right]-\mathbf{8 h}$, and $\left[{ }^{18} \mathrm{~F}\right]-\mathbf{8 i}$ were 14.576, 19.197, 6.696, and $6.668 \mathrm{~min}$, respectively, which matched well with the corresponding F-19 standards 8a (14.301 min), 8c (18.899 $\mathrm{min}), \mathbf{8 h}$ (6.357 $\mathrm{min})$, and $\mathbf{8 i}$ (6.313 $\mathrm{min}$ ) within admissible error, respectively (Fig. 4).

\section{Partition coefficient determination}

Selecting potential candidates as FAK targeting tumor imaging agents for further development requires measuring a range of physiochemical properties. ${ }^{33}$ The partition coefficient $(\log P)$ value governs various biological processes, such as the transportation, distribution, metabolism, and secretion of biomolecules, which is essential to predict their transportation and activity. Therefore, the selected compounds $\left[{ }^{18} \mathrm{~F}\right]-8 \mathrm{a},\left[{ }^{18} \mathrm{~F}\right]-\mathbf{8 c}$, $\left[{ }^{18} \mathrm{~F}\right]-\mathbf{8 h}$, and $\left[{ }^{18} \mathrm{~F}\right]-8 \mathbf{i}$ were measured for their $\log P$ values.

Table 2 shows that the $\log P$ values of the four measured compounds were all over 0 . The results indicated that the four compounds were all liposoluble. Notably, the $\log P$ value of compound $\left[{ }^{18} \mathrm{~F}\right]-8 \mathrm{a}$ (4.51) was higher than the others. The difference might result from the substituents, such as trifluoromethyl and the carboxyl groups on compounds $\left[{ }^{18} \mathrm{~F}\right]-\mathbf{8 c}$, $\left[{ }^{18} \mathrm{~F}\right]-\mathbf{8 h}$, and $\left[{ }^{18} \mathrm{~F}\right]-\mathbf{8 i}$, which increased their hydrophilicity.
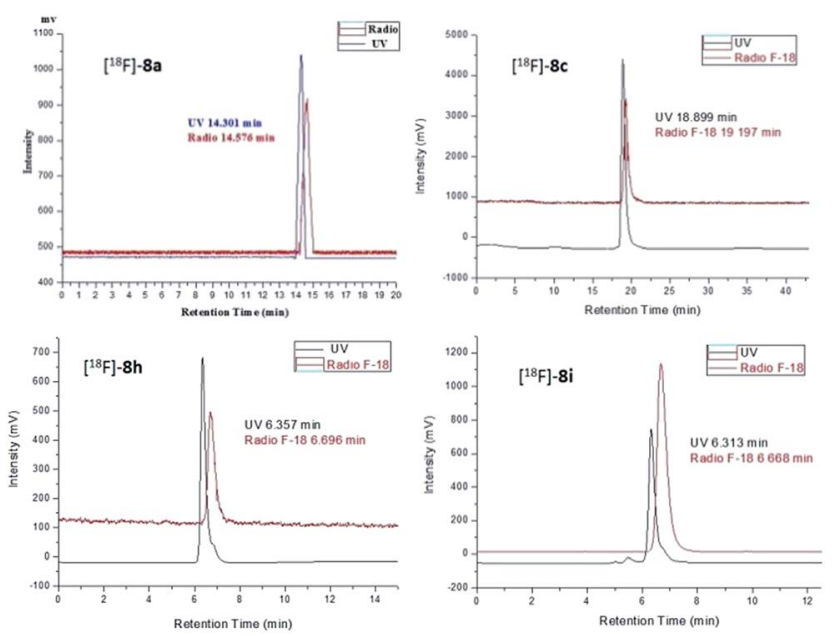

Fig. 4 HPLC chromatogram of the ${ }^{18} \mathrm{~F}$-labeled radiotracers and the corresponding ${ }^{19} \mathrm{~F}$ standards.

Table $2 \log P$ values of compounds $\left[{ }^{18} \mathrm{~F}\right]-8 \mathrm{a},\left[{ }^{18} \mathrm{~F}\right]-8 \mathrm{c},\left[{ }^{18} \mathrm{~F}\right]-8 \mathrm{~h}$, and $\left[{ }^{18} \mathrm{~F}\right]-8 \mathrm{i}$

\begin{tabular}{lllll}
\hline Compds & {$\left[{ }^{18} \mathrm{~F}\right]-8 \mathrm{a}$} & {$\left[{ }^{18} \mathrm{~F}\right]-\mathbf{8 c}$} & {$\left[{ }^{18} \mathrm{~F}\right]-\mathbf{8 h}$} & {$\left[{ }^{18} \mathrm{~F}\right]-8 \mathbf{i}$} \\
$\log P$ & $4.51 \pm 0.04$ & $1.63 \pm 0.04$ & $1.22 \pm 0.06$ & $1.35 \pm 0.05$
\end{tabular}

\section{In vitro stability studies}

The in vitro stability of $\left[{ }^{18} \mathrm{~F}\right]-\mathbf{8 a},\left[{ }^{18} \mathrm{~F}\right]-\mathbf{8 c},\left[{ }^{18} \mathrm{~F}\right]-\mathbf{8 h}$, and $\left[{ }^{18} \mathrm{~F}\right]-\mathbf{8 i}$ were determined in physiological saline and mouse plasma. Radio-HPLC analysis of the physiological saline and mouse plasma samples revealed that compounds $\left[{ }^{18} \mathrm{~F}\right]-8 \mathrm{a},\left[{ }^{18} \mathrm{~F}\right]-8 \mathrm{c}$, $\left[{ }^{18} \mathrm{~F}\right]-\mathbf{8 h}$, and $\left[{ }^{18} \mathrm{~F}\right]-8 \mathbf{i}$ remained sufficiently stable $(>95 \%)$ during incubation at $37{ }^{\circ} \mathrm{C}$ for $2 \mathrm{~h}$, demonstrating a high in vitro stability of these radio-compounds (Fig. 5).

\section{In vivo biodistribution studies in S180-bearing mice}

In vivo biodistribution data in mice bearing the $\mathrm{S} 180$ tumor for $\left[{ }^{18} \mathrm{~F}\right]-8 \mathrm{a}$ at $5,15,30,60$, and $120 \mathrm{~min}$ are shown in Table 1 , while for compounds $\left[{ }^{18} \mathrm{~F}\right]-\mathbf{8 c},\left[{ }^{18} \mathrm{~F}\right]-\mathbf{8 h}$, and $\left[{ }^{18} \mathrm{~F}\right]-\mathbf{8 i}$ the date are shown in the ESI. $\dagger$ The results in Table 1 display that $\left[{ }^{18} \mathrm{~F}\right]-8 \mathbf{a}$ was
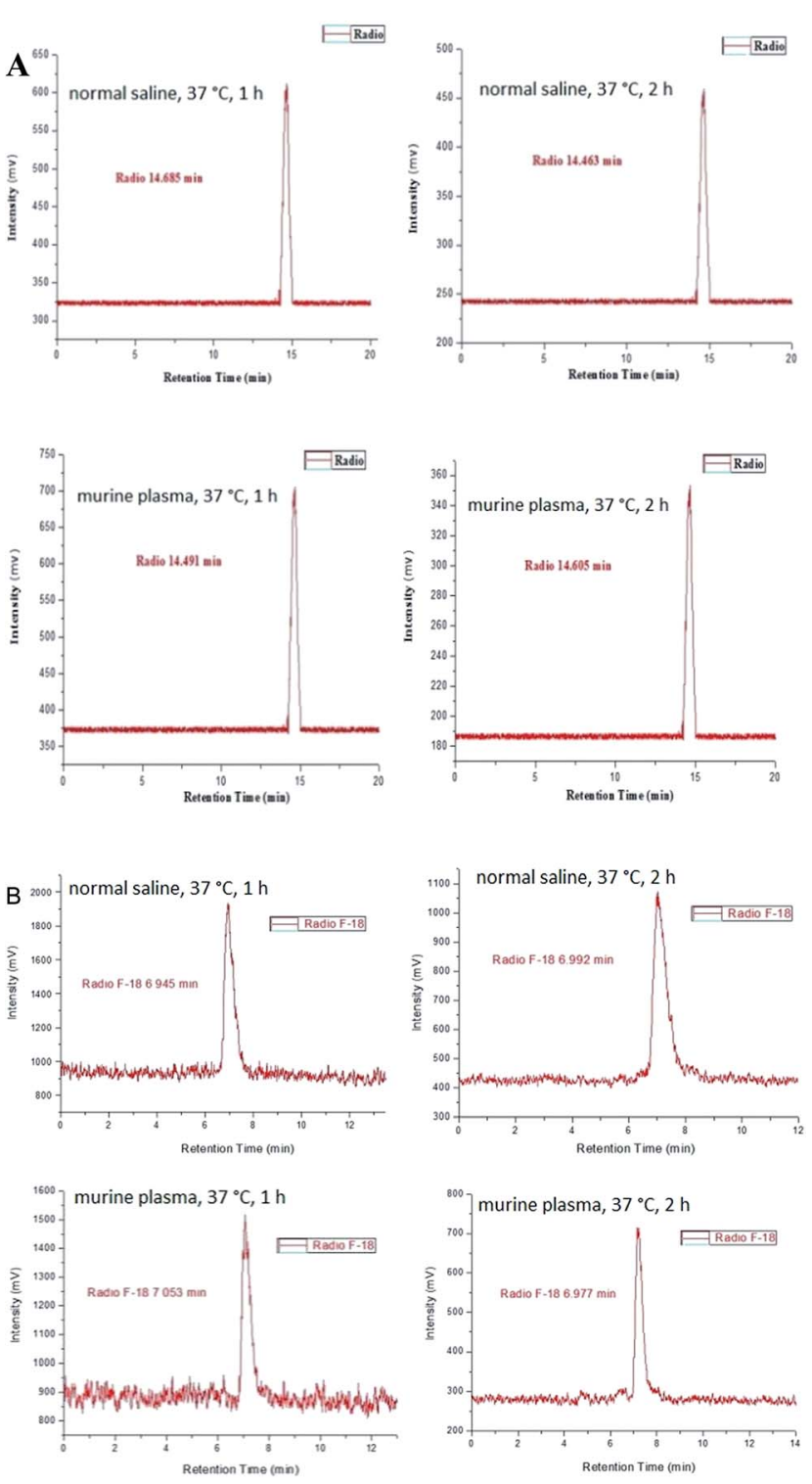

Fig. 5 (A) HPLC chromatograms of [18F]-8a in normal saline and murine plasma at $37^{\circ} \mathrm{C}$ after $1 \mathrm{~h}$ and $2 \mathrm{~h}$, respectively. (B) HPLC chromatograms of $\left[{ }^{18} \mathrm{~F}\right]-8 \mathrm{i}$ in normal saline and murine plasma at $37^{\circ} \mathrm{C}$ after $1 \mathrm{~h}$ and $2 \mathrm{~h}$, respectively. 
Table 3 Biodistribution of $\left[{ }^{18} \mathrm{~F}\right]-8$ in mice bearing the S180 tumor $^{a}$

\begin{tabular}{|c|c|c|c|c|c|}
\hline $\mathrm{ID} \%\left(\mathrm{~g}^{-1}\right)$ & $5 \mathrm{~min}$ & $15 \mathrm{~min}$ & $30 \mathrm{~min}$ & $60 \mathrm{~min}$ & $120 \mathrm{~min}$ \\
\hline Blood & $1.95 \pm 0.32$ & $1.99 \pm 0.09$ & $2.19 \pm 0.01$ & $1.9 \pm 0.10$ & $0.81 \pm 0.01$ \\
\hline Brain & $1.20 \pm 0.12$ & $0.78 \pm 0.03$ & $1.19 \pm 0.18$ & $1.51 \pm 0.12$ & $0.91 \pm 0.03$ \\
\hline Liver & $3.29 \pm 0.02$ & $1.99 \pm 0.23$ & $1.87 \pm 0.19$ & $1.41 \pm 0.08$ & $0.50 \pm 0.06$ \\
\hline Spleen & $1.98 \pm 0.03$ & $1.65 \pm 0.11$ & $2.28 \pm 0.12$ & $1.74 \pm 0.19$ & $0.75 \pm 0.23$ \\
\hline Lung & $6.98 \pm 0.09$ & $8.01 \pm 0.17$ & $6.30 \pm 0.18$ & $2.26 \pm 0.12$ & $1.25 \pm 0.06$ \\
\hline Intest $^{b}$ & $1.18 \pm 0.02$ & $1.59 \pm 0.03$ & $3.46 \pm 0.26$ & $3.51 \pm 0.14$ & $3.03 \pm 0.19$ \\
\hline Stom $^{b}$ & $1.14 \pm 0.21$ & $1.33 \pm 0.06$ & $1.49 \pm 0.08$ & $1.61 \pm 0.04$ & $1.35 \pm 0.05$ \\
\hline Tumor & $3.69 \pm 0.51$ & $3.39 \pm 0.25$ & $3.11 \pm 0.22$ & $3.71 \pm 0.43$ & $3.23 \pm 0.14$ \\
\hline $\mathrm{Tu} / \mathrm{Mu}^{c}$ & 2.67 & 2.31 & 1.80 & 1.88 & 2.03 \\
\hline $\mathrm{Tu} / \mathrm{Bo}^{c}$ & 1.96 & 1.64 & 0.90 & 0.95 & 0.65 \\
\hline $\mathrm{Tu} / \mathrm{Bl}^{c}$ & 1.89 & 1.70 & 1.42 & 1.92 & 3.99 \\
\hline
\end{tabular}

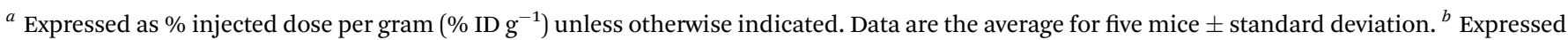
as $\%$ injected dose per organ (\% ID), intest $=$ intestine, stom $=$ stomach. ${ }^{c} \mathrm{Tu} / \mathrm{Mu}=$ tumor $/ \mathrm{muscle}, \mathrm{Tu} / \mathrm{Bo}=$ tumor $/ \mathrm{bone}, \mathrm{Tu} / \mathrm{Bl}=\mathrm{tumor} / \mathrm{blood}$.

accumulated in the tumor with retention values between $3.11 \pm$ 0.22 and $3.71 \pm 0.43$. At $60 \mathrm{~min}$ post-injection, $\left[{ }^{18} \mathrm{~F}\right]-8 \mathrm{a}$ had the highest uptake in the tumor $\left(3.71 \pm 0.43 \mathrm{ID}_{\mathrm{O}} \mathrm{g}^{-1}\right)$. The uptake by the tumor of $\left[{ }^{18} \mathrm{~F}\right]-8 \mathrm{a}$ was found to be at least 2 times more than the uptake in the liver $\left(1.41 \pm 0.08 \mathrm{ID}^{\mathrm{m}} \mathrm{g}^{-1}\right)$ and in the kidney $\left(1.49 \pm 0.13 \mathrm{ID} \% \mathrm{~g}^{-1}\right)$. Also, a good to moderate uptake was observed in other major organs or tissues, such as the intestine $\left(3.51 \pm 0.14 \mathrm{ID}^{2} \mathrm{~g}^{-1}\right)$, heart $\left(3.12 \pm 0.18 \mathrm{ID} \% \mathrm{~g}^{-1}\right)$, lung $(2.26 \pm$ $\left.0.12 \mathrm{ID}^{2} \mathrm{~g} \mathrm{~g}^{-1}\right)$, and muscle $\left(1.97 \pm 0.25 \mathrm{ID} \% \mathrm{~g}^{-1}\right)$ at $60 \mathrm{~min}$ postinjection. Since most PET-based radiotracer studies are generally performed within $60 \mathrm{~min}$ of the radiotracer administration, ${ }^{34}$ thus $\left[{ }^{18} \mathrm{~F}\right]$-8a seems suitable for early tumor imaging (Table 3 ).

\section{MicroPET imaging}

Compound $\left[{ }^{18} \mathrm{~F}\right]-8 \mathrm{a}$ was selected as the microPET imaging agent in the four F-18-labeled pyrimidine derivatives for its good in vivo biodistribution in mice bearing the S180 tumor. In the microPET images, it could be seen that the diffusion of the $\left[{ }^{18} \mathrm{~F}\right]$ 8a in vivo needed a period of time, and with the time increasing, the accumulation of $\left[{ }^{18} \mathrm{~F}\right]-8 \mathrm{a}$ increased close to the tissue of the tumor. It is worth noting that after $60 \mathrm{~min}$ of caudal intravenous injection for $\left[{ }^{18} \mathrm{~F}\right]-\mathbf{8 a}$, the intensity of radioactivity in the urinary

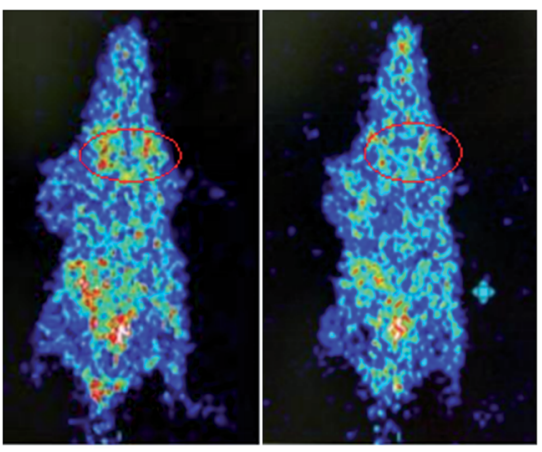

Fig. 6 MicroPET images of $\left[{ }^{18} \mathrm{~F}\right]-8 \mathrm{a}$ at $60 \mathrm{~min}$ (left) and $120 \mathrm{~min}$ (right) of $\mathrm{S} 180$-bearing nude mice. bladders of the mice could be clearly observed, which might be responsible for the metabolism of $\left[{ }^{18} \mathrm{~F}\right]-8 \mathrm{a}$ in mice kidney. These results were in accordance with the data for the in vivo biodistribution (Fig. 6).

\section{Conclusions}

In conclusion, a series of novel pyrimidine derivatives were successfully synthesized and characterized by ${ }^{1} \mathrm{H} N M R,{ }^{13} \mathrm{C}$ HNMR, and MS spectra. All the new compounds were evaluated for their activity against $\mathrm{FAK}$, and showed low $\mathrm{IC}_{50}$ values in comparison with control drugs. Especially for compound 8i, its $\mathrm{IC}_{50}$ value was $0.060 \mu \mathrm{M}$, suggesting its advantage as an FAK inhibitor. To evaluate the potentiality of these compounds as PET imaging agents in cancer detection, compounds $\mathbf{8 a}, \mathbf{8 c}, \mathbf{8 h}$, and $\mathbf{8 i}$ were successively labeled with ${ }^{18} \mathrm{~F}$. The four ${ }^{18} \mathrm{~F}$-labeled pyrimidine derivatives $\left[{ }^{18} \mathrm{~F}\right]-\mathbf{8 a},\left[{ }^{18} \mathrm{~F}\right]-\mathbf{8 c},\left[{ }^{18} \mathrm{~F}\right]-\mathbf{8 h}$, and $\left[{ }^{18} \mathrm{~F}\right]-\mathbf{8 i}$ showed appropriate $\log P$ values and high stability in physiological saline and mouse plasma. Noticeably, compound $\left[{ }^{18} \mathrm{~F}\right]-8 \mathrm{a}$ with a 4 methoxyl group at the benzene ring exhibited good in vivo biodistribution data in mice bearing the S180 tumor, which promoted its further microPET imaging study. MicroPET image of $\left[{ }^{18} \mathrm{~F}\right]-8 \mathrm{a}$ administered into S180-tumor-bearing mice acquired at 60 min post-injection illustrated that the uptake in the S180 tumor was obvious. These results suggested that compound $\left[{ }^{18} \mathrm{~F}\right]$ 8a might be a promising PET tracer candidate for tumor detection. On the other hand, on-going efforts to optimize the structure of $\left[{ }^{18} \mathrm{~F}\right]-8 \mathrm{a}$ aimed at enhancing the tumor-to-nontarget ratios in vivo are under way. Furthermore, in order to enhance the uptake of the F-18-labeled tracer in tumor and its target/ nontarget ratios, the interaction between the corresponding F19 standards and the FAK should be further increased and the $\log P$ should be further properly lowered in future designs.

\section{Compliance with ethical standards}

All protocols requiring the use of mice were approved by the Animal Care Committee of Beijing Normal University. 


\section{Acknowledgements}

This work was supported by the National Major Scientific and Technological Special Project for "Significant New Drugs Development" (Grant No. 2014ZX09507007-001 and 2014ZX09507007003); the National Science and Technology Support Program (Grant No. 2014BAA03B03) and the National Natural Science Foundation of China (Grant No. 21371026). We also thank the Nuclear Medicine Department of Peking Cancer Hospital (Beijing, China) for providing the fluoride-18 nuclide and the use of the Micro PET of Peking Union Medical College Hospital (Beijing, China).

\section{Notes and references}

1 L. A. Torre, F. Bray, R. L. Siegel, J. Ferlay, J. Lortet-Tieulent and A. Jemal, Ca-Cancer J. Clin., 2015, 65, 87.

2 Y. Y. Wang, Y. He, L. F. Yang, S. H. Peng, X. L. He, J. H. Wang, F. Lv, Y. Hao, M. Y. Liu, Z. F. Yi and W. W. Qiu, Eur. J. Med. Chem., 2016, 120, 13.

3 M. X. Zhao, H. Y. Ren, J. Chang, D. Q. Zhang, Y. T. Yang, Y. He, C. M. Qi and H. B. Zhang, Eur. J. Med. Chem., 2016, 119, 183.

4 J. R. Beck, X. Q. Zhou, G. R. Casey and C. I. Stains, Anal. Chim. Acta, 2015, 897, 62.

5 P. Dao, N. Smith, C. Tomkiewicz-Raulet, E. Yen-Pon, M. Camacho-Artacho, D. Lietha, J. P. Herbeuval, X. Coumoul, C. Garbay and H. X. Chen, J. Med. Chem., 2015, 58, 237.

6 J. Zhang and S. N. Hochwald, Pharmacol. Ther., 2014, 142, 154.

7 T. Lechertier and K. Hodivala-Dilke, J. Pathol., 2012, 226, 404. 8 M. A. Cabrita, L. M. Jones, J. L. Q. Z. Lu, A. Sabourin, B. C. McKay and C. L. Addison, Mol. Oncol., 2011, 5, 517.

9 W. W. Ma, Anti-Cancer Agents Med. Chem., 2011, 11, 638.

10 T. Heinrich, J. Seenisamy, L. Emmanuvel, S. S. Kulkarni, J. Bomke, F. Rohdich, H. Greiner, C. Esdar, M. Krier, U. Grädler and D. Musil, J. Med. Chem., 2013, 56, 1160.

11 U. Grädler, J. Bomke, D. Musil, V. Dresing, M. Lehmann, G. Hölzemann, H. Greiner, C. Esdar, M. Krier and T. Heinrich, Bioorg. Med. Chem. Lett., 2013, 23, 5401.

12 Q. Shi, A. B. Hjelmeland, S. T. Keir, L. H. Song, S. Wickman, D. Jackson, O. Ohmori, D. D. Bigner, H. S. Friedman and J. N. Rich, Mol. Carcinog., 2007, 46, 488.

13 E. A. Beierle, A. Trujillo, A. Nagaram, V. M. Golubovskaya, W. G. Cance and E. V. Kurenova, Cancer Invest., 2008, 26, 145.

14 V. M. Golubovskaya, C. Virnig and W. G. Cance, Mol. Carcinog., 2008, 47, 222.
15 N. Kurio, T. Shimo, T. Fukazawa, M. Takaoka, T. Okui, N. M. Hassan, T. Honami, S. Hatakeyama, M. Ikeda, Y. Naomoto and A. Sasaki, Exp. Cell Res., 2011, 317, 1134.

16 J. Halder, Y. G. Lin, W. M. Merritt, W. A. Spannuth, A. M. Nick, T. Honda, A. A. Kamat, L. Y. Han, T. J. Kim, C. H. Lu, A. M. Tari, W. Bornmann, A. Fernandez, G. Lopez-Berestein and A. K. Sood, Cancer Res., 2007, 67, 15. 17 A. Schultze and W. Fiedler, Anti-Cancer Agents Med. Chem., 2011, 11, 593.

18 J. K. Slack-Davis, K. H. Martin, R. W. Tilghman, M. Lwanicki, E. J. Ung, C. Autry, M. J. Luzzio, B. Cooper, J. C. Kath, W. G. Roberts and J. T. Parsons, J. Biol. Chem., 2007, 282, 14845.

19 N. Malik, P. Dhiman, P. K. Verma and A. Khatkar, Res. Chem. Intermed., 2015, 41, 7981.

20 A. A. Abu-Hashema and F. A. Badria, J. Chin. Chem. Soc., 2015, 62, 506.

21 O. S. Reddy, Ch. V. Suryanarayana, K. J. P. Narayana, V. Anuradha and B. H. Babu, Med. Chem. Res., 2014, 24, 1777.

22 H. J. Ma, J. H. Zhang, X. D. Xia, J. Kang and J. H. Li, Pest Manage. Sci., 2015, 71, 1189.

23 P. Brust, W. Deuther-Conrad, K. Lehmkuhl, H. Jia and B. Wunsch, Curr. Med. Chem., 2014, 21, 35.

24 P. W. Miller, N. J. Long, R. Vilar and A. D. Gee, Angew. Chem., Int. Ed., 2008, 47, 8998.

25 Y. Y. Chen, X. Wang, J. M. Zhang, W. Deuther-Conrad, X. J. Zhang, Y. Y. Huang, Y. Li, J. J. Ye, M. C. Cui, J. Steinbach, P. Brust, B. L. Liu and H. M. Jia, Bioorg. Med. Chem., 2014, 22, 5270.

26 S. Bai, S. G. Li, J. Xu, X. Peng, K. Sai, W. Chu, Z. Tu, C. Zeng and R. H. Mach, J. Med. Chem., 2014, 57, 4239.

27 M. W. Moon and R. A. Wade, J. Org. Chem., 1984, 49, 2663.

28 K. Niikura, N. Iyo, T. Higuchi, T. Nishio, H. Jinnai, N. Fujitani and K. Ijiro, J. Am. Chem. Soc., 2012, 134, 7632.

29 L. Ding, M. Xu, J. Wang, Y. Liao and J. Qiu, Polymer, 2014, 55, 1681.

30 E. V. Malykhin and V. D. Shteingarts, Russ. J. Appl. Chem., 2012, 85, 1232.

31 T. M. Rangarajan, R. Singh, R. Brahma, K. Devi, R. P. Singh, R. P. Singh and A. K. Prasad, Chem.-Eur. J., 2014, 20, 14218.

32 H. Lee, D. L. Chen, J. M. Rothfuss, M. J. Welch, R. J. Gropler and R. H. Mach, Nucl. Med. Biol., 2012, 39, 77.

33 L. Gilfillan, A. Blair, B. J. Morris, J. A. Pratt, L. Schweiger, S. Pimlott and A. Sutherland, Med. Chem. Commun., 2013, 4, 1118.

34 I. AlJammaz, B. Al-Otaibi, H. AlHindas and S. M. Okarvi, Nucl. Med. Biol., 2015, 42, 804. 